\title{
Evolution of a sedimentary infill of a palaeovalley at a distal margin of the peripheral foreland basin
}

\author{
Slavomír NEHYBA ${ }^{1}$, Helena GILÍKOVÁ2, Pavla Tomanová PETROVÁ2, \\ Jiří OTAVA ${ }^{2}$ and Zuzana SKÁCELOVÁ ${ }^{3}$ \\ 1 Masaryk University, Faculty of Science, Department of Geological Sciences, Kotlářská 2, 61137 Brno, Czech Republic \\ 2 Czech Geological Survey, Leitnerova 22, 60200 Brno, Czech Republic \\ 3 Czech Geological Survey, Erbenova 348, 79000 Jeseník, Czech Republic
}

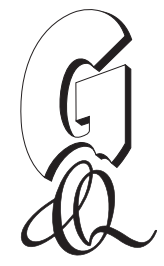

Nehyba, S., Gilíková, H., Petrová, P.T., Otava, J., Skácelová, Z., 2019. Evolution of a sedimentary infill of a palaeovalley at a distal margin of the peripheral foreland basin. Geological Quarterly, 63 (2): 319-344, doi: 10.7306/gq.1469

Associate Editor - Anna Wysocka

The entrenched Odra palaeovalley, cut into the bedrock of the distal margin (forebulge basal unconformity) of the Moravian Carpathian Foredeep (peripheral foreland basin) is filled with an almost 300 m thick pile of Miocene deposits. The directon of the valley (NW-SE to NNW-SSE) has been controlled by faults subparallel with the system of "sudetic faults". The sedimentary succession consists of 5 facies associations/depositional environments, which are interpreted (from bottom to top, i.e. from the oldest to the youngest) as: 1 - colluvial deposits to deposits of alluvial fan, 2 - deposits of alluvial fan, 3 - fan-delta deposits, 4 - shallow water delta to nearshore deposits and 5 - open marine deposits. This fining-up and deepening-up succession reveals the following: the formation of the new flexural shape of the basin; deep erosion connected with uplift and tilting of the forebulge and reactivation of the NW-SE trending basement faults; the Early/Middle Miocene sea level fall; alluvial deposition mostly driven by tectonics and morphology; forebulge flexural retreat; Middle-Miocene sea level rise; back-stepping of valley infill; marine invasion during the Early Badenian with shift of the coastline further landward of the pallaeovalley. Tectonics related to contemporary thrusting processes in the Western Carpathians are assumed to be the dominating factor of the studied deposition at the expense of eustatic sea level changes. Provenance studies have proven that the pre-Neogene basement (i.e. the Early Carboniferous clastic "Culmian facies" of the Moravian-Silesian Paleozoic) represents an important source for the conglomerates and sands, which volumetrically dominate in the palaeovalley infill. However, they also showed, that the deposits of the earlier Carpathian Foredeep Basin sedimentary stage (Karpatian in age?) covered the area under study and were eroded and resedimented into the palaeovalley infill.

Key words: peripheral foreland basin, Neogene, forebulge, confined valley, facies analysis, provenance study.

\section{INTRODUCTION}

The palaeovalleys located along the basal unconformity in the foreland plate that fed with sediments the distal part of the foreland basin provide unique information about the flexurally induced sea level changes, the foreland palaeodrainage network or the role of external factors (climate, tectonics, sediment supply and palaeogeomorphology) and constitute basic data for the stratigraphic organisation of these sedimentary basins (Gupta, 1999; Dalrymple, 2004). The enormous diversity of valley sizes, shapes, settings, infill, and potential for hydrocarbon reservoirs make them a relatively common target of study

\footnotetext{
* Corresponding author, e-mail: slavek@sci.muni.cz
} Received: October 11, 2018; accepted: March 12, 2019; first published online: June 6, 2019
(Zaitlin et al., 1994; Gupta, 1999; Dalrymple, 2004; Breda et al., 2007 etc.).

This paper is focused on sedimentary infill of a Miocene entrenched valley located near the town of Odry at the northwestern margin of the Carpathian Foredeep Basin (Moravia, Czech Republic; Fig. 1). Although the valley is remarkably manifested in the present landscape (Fig. 2), its infill is known from subsurface data only. The presented study has several goals:

- to provide a sedimentological and provenance analysis of the valley sedimentary infill;

- to assess the valley development based on sequence stratigraphic concepts (sediment supply, accommodation space, role of tectonics and eustasy);

- to examine factors that determined the location and geometry of the valley.

The study aims to contribute to a better understanding of the Carpathian Foredeep Basin depositional system and provide further data for the spectrum of foreland entrenched valleys. 

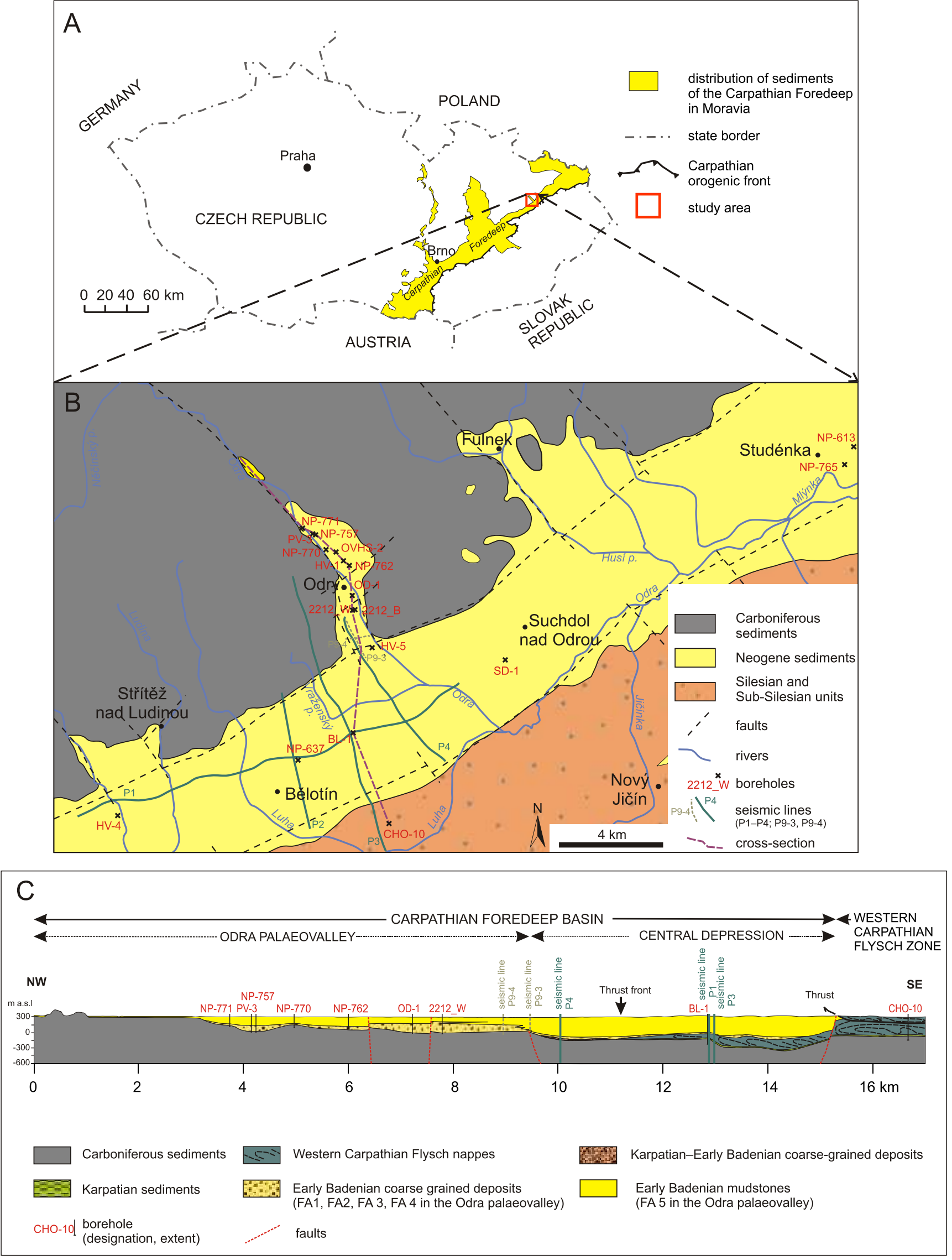

Fig. 1A - geographic location of the area under study with position of the studied area within the Moravian part of the Carpathian Foredeep; B - simplified geological map of the broader surroundings of the Odra palaeovalley with position of evaluated boreholes, geophysical profiles and cross-section; C - representative geological cross-sections across the Odry palaeovalley and adjacent Central Depression of the Carpathian Foredeep Basin with distribution of recognized facies associations 


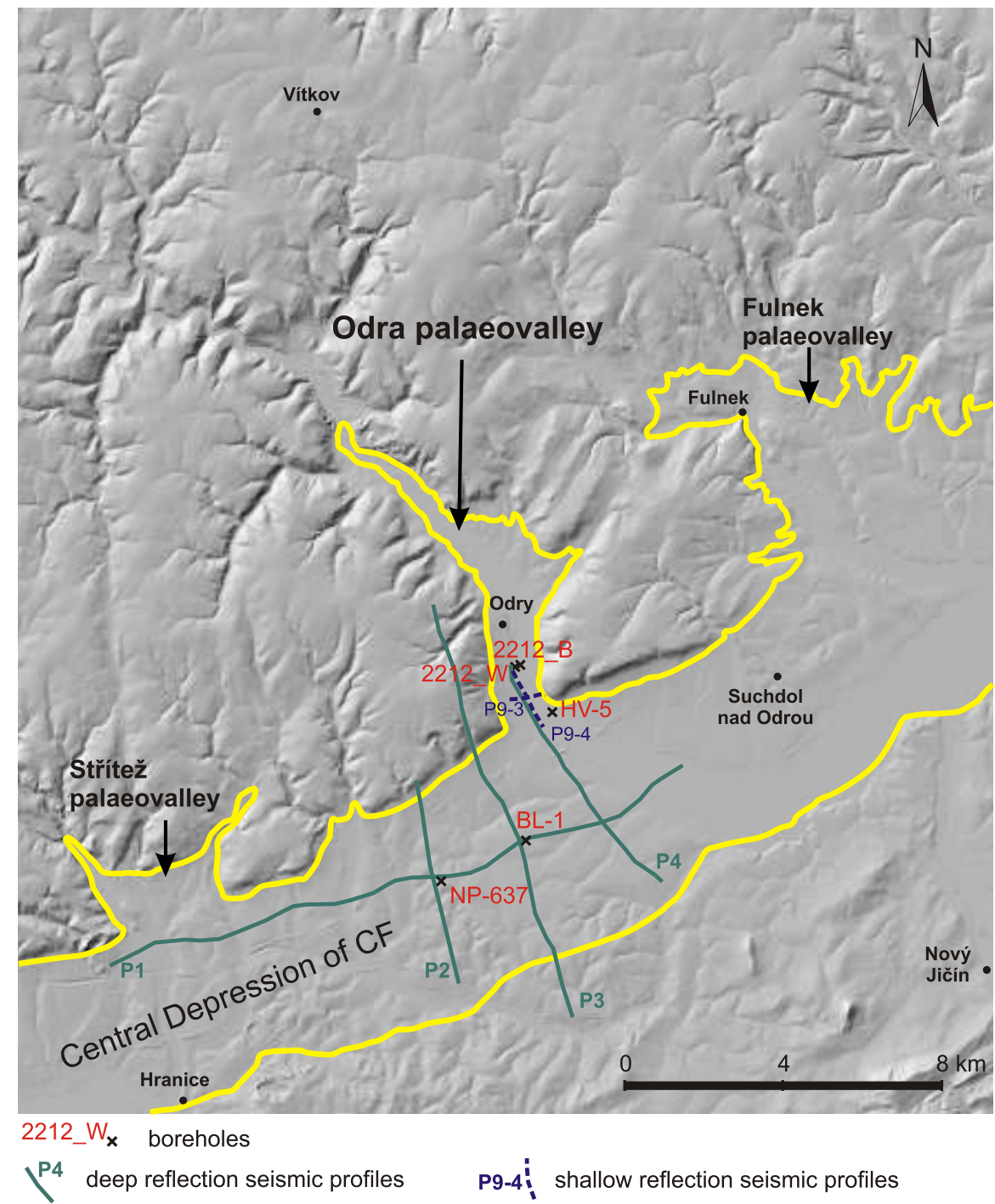

Fig. 2. DEM 4G image of the present day structure of the Odra palaeovalley with position of evaluated boreholes, geophysical profiles

\section{GEOLOGICAL SETTING}

The western Moravian part of the Carpathian Foredeep (MCF), where the study area is located, represents a peripheral foreland basin formed due to the tectonic emplacement and crustal loading of the Alpine-Carpathian thrust wedge onto the passive margin of the Bohemian Massif (Nehyba and Šikula, 2007; Fig. 1). The basin continues north-east into the Polish Carpathian Foredeep Basin (Oszczypko et al., 2006) and south-west into the North Alpine Foreland Basin (Nehyba and Roetzel, 2010). The lithological and stratigraphical content and basin architecture varies in various parts of the MCF. Local and regional unconformities are developed due to the varying intensity and orientation of flexural loading and different geologic and tectonic histories of the basement, along with a polyphase nature of the active basin margin and gradual change of its position (Brzobohatý and Cicha, 1993; Eliáš and Pálenský, 1998; Krzywiec, 2001; Kováč et al., 2003, 2004; Oszczypko et al., 2006; Francírek and Nehyba, 2016).

The pre-Neogene bedrock of the studied segment of the MCF is formed by Devonian to Early Carboniferous carbonates and siliciclastics ("Culmian facies") of the Moravian-Silesian Paleozoic (Kalvoda et al., 2008). Geological or geophysical evidence of major, deep, fore- and sub-Carpathian palaeovalleys (similar to Vranovice and Nesvačilka palaeovalleys - see Picha, 1979; Picha et al., 2006) or of autochtonous Paleogene beds are completely missing from the studied northern segment of the MCF (in contrast to the southern segment). Deposition in the MCF basin started in the Eggerian/Eggenburgian and lasted up to the Late Badenian (Fig. 3). However, Eggenburgian and Ottnangian deposits here are very rare (Jurková et al., 1983). Deposition during the Karpatian was here evaluated by Adámek et al. (2003) and Francírek and Nehyba (2016). The Karpatian depositional cycle is connected with a shift of the basin axis to the north-west due to continued thrusting of the Outer Carpathian flysch wedge (Brzobohatý and Cicha, 1993), which also led to the overriding of a significant part of the Carpathian Foredeep by the flysch nappes and partial incorporation of the basin infill into the orogenic wedge.

Peripheral foreland basins are known by their distinctive depositional architecture and facies distribution i.e. a strong tendency for lateral asymmetry of sedimentary facies and stratal patterns of marginal and internal depositional systems 


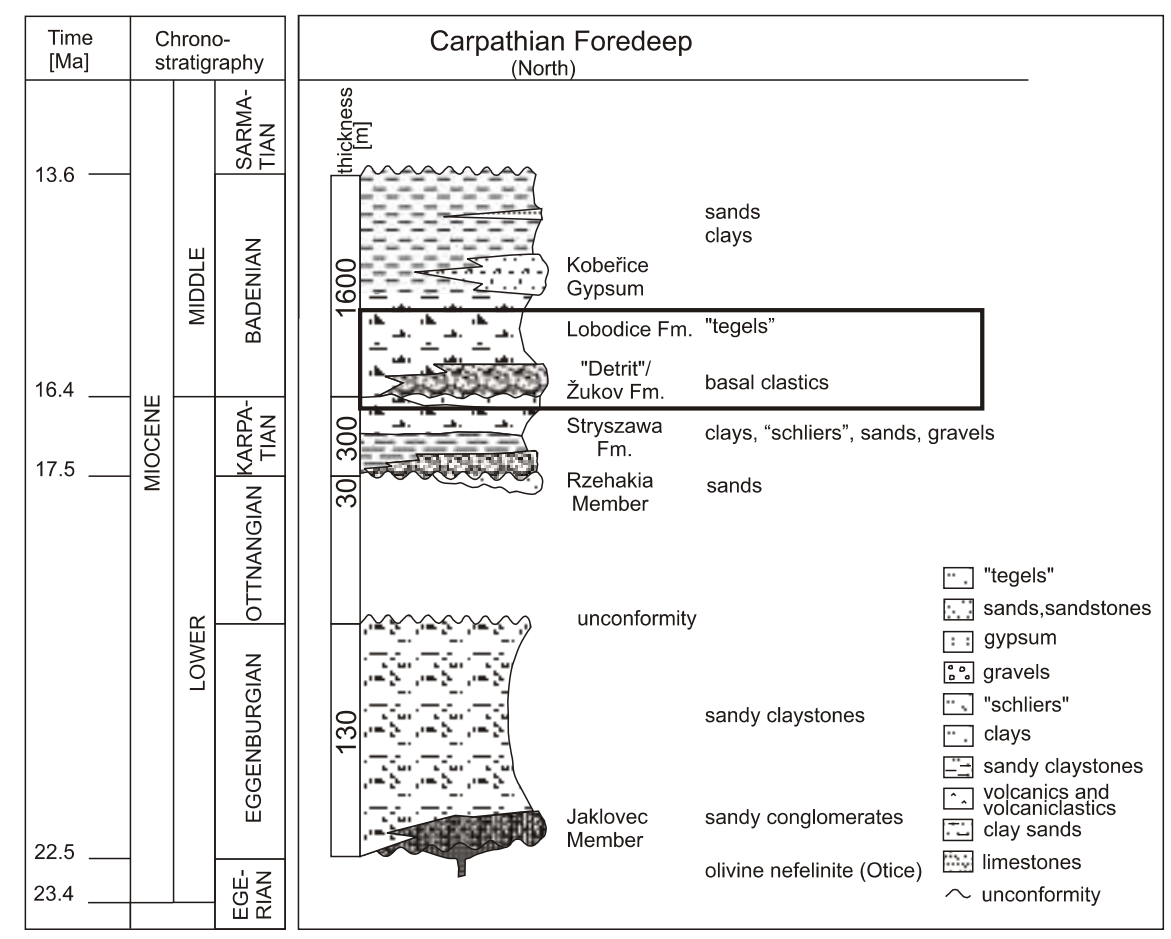

Fig. 3. Generalized stratigraphic scheme of the infill of the northern segment of the Moravian part of the Carpathian Foredeep with estimated stratigraphic extent of the Odra palaeovalley deposits (modified after Chlupáč et al., 2002)

(Beaumont, 1981). "Coarse-grained (steep gradient)" sedimentary systems are here commonly deposited along basin margins, whereas "fine-grained (gentle-gradient)" depositional system are developed in the central parts of the basin. The Early Badenian deposits of MCF typically reveal such distinctive basin infill geometry (Nehyba and Šikula, 2007). The volumetrically dominant part of the basin assigned as "Central Depression" (Eliáš and Pálenský, 1998) oriented in the direction $\mathrm{NE}-\mathrm{SW}$ is accompanied by several minor "hanging" valleys oriented transverse i.e. in NW-SE direction (the Odra Valley represents one of these valleys see Fig. 2). The Early Badenian deposition in the Central Depression started with coarse-grained deposits locally known as "Detrit", an equivalent of the Dębowiec conglomerate in Poland (Eliáš et al., 2002; Oszczypko et al., 2006). These poorly sorted polymict gravels, conglomerates and breccias are up to 280 m thick (Jurková, 1959, 1961; Eliáš and Pálenský, 1998). Coarse-grained deposits are locally known also from the sedimentary infill of the transverse valleys commonly depicted under several local lithostratigraphic names (Jerlochovice sandstones, Stachovice development - see Gilíková et al., 2006) and are generally assigned as Žukov Fm. (Eliáš et al., 2002). These deposits can reach more than $130 \mathrm{~m}$ in thickness and are interpreted as mass-flow deposits (Eliáš and Pálenský, 1998; Nehyba et al., 2009). Overlying marine clays called "Tegel" cover both the deposits of Žukov Fm. and also the pre-Neogene basement towards NW. These volumetrically predominant deposits can reach up to $1100 \mathrm{~m}$ in thickness and belong to Lobodice Fm. (Eliáš et al., 2002). They were generally interpreted as open marine or even hemipelagic deposits rich in microfauna (Tomanová Petrová and Švábebnická, 2007; Nehyba et al., 2008; Kopecká, 2012). Interbeds of red-algal limestones are in the northern segment of the MCF very rare (Doláková et al., 2008). Rare and thin interlayers of acidic tuffs and tuffites are interpreted as distal tephra fallout (Nehyba et al., 1999).
Termination of the continuous MCF Basin (Mid- to Late Badenian) is explained by the final "Late Styrian" phase of thrusting and uplift of the southern and northern segment of the basin (Brzobohatý and Cicha, 1993). Middle Badenian deposition continued here only in the broader surrounding of Opava, where it terminated during the Late Badenian (Brzobohatý and Cicha, 1993). The evolution of the Carpathian Foredeep Basin continued further to the north and east in what is today Poland and Ukraine (Oszczypko et al., 2006).

The Odra palaeovalley is located NW and SE of the town of Odry and forms a morphologically distinct feature of the eastern flanks of the Bohemian Massif. The present-day structure of the Odra palaeovalley (Fig. 2) reveals an almost regular rectangular shape prolonged in the NW-SE direction. The valley is about $9 \mathrm{~km}$ long and up to $1.8 \mathrm{~km}$ wide near its SE termination. The valley shows a flat bottom with a longitudinal profile dipping only a few degrees, thought the flank inclination is about $20^{\circ}$. The margins of the valley are about 100-150 m higher than its central part, they have an almost straight parallel course oriented perpendicular to the marginal fault of the MCF (see Figs. 1 and 2). The tectonic origin of the valley has been discussed by Czudek (1971) and Jurková (1971, 1985). Neogene (Early Badenian) deposits fill the valley with a maximum thickness of about 300 m (Jurková, 1971; see Fig. 1C). Pleistocene fluvial deposits of the Odra River, deluvio-fluvial deposits (up to $15 \mathrm{~m}$ thick), loesses (up to $18 \mathrm{~m}$ thick) and glacio-lacustrine deposits represent the Quaternary infill of the valley.

\section{METHODS}

The study area is devoid of natural outcrops of Neogene deposits. The presented results are principally based on sedimentological logging of two adjacent boreholes 2212_B 
Odry and 2212 W Odry (drilled in 2015) which together provided an almost completely cored profile of the infill of the Odra palaeovalley. Further information was provided by an evaluation of the available wire-line logs (i.e. gamma-ray log, neutron-neutron log and natural radioactivity log; Rider, 1996) and from a general lithological description and stratigraphy of a 15 additional older boreholes. The location of boreholes is shown in Figures $1 \mathrm{~B}$ and 2. The lithofacies analysis followed Walker and James (1992) and Tucker (1995). Facies were a source of information on the depositional processes. Spatially and genetically related facies were grouped into several facies associations representing particular sedimentary environments.

Combined sieving and laser methods were used for grain size analysis (55 analyses). A Retsch AS 200 sieving machine analysed the coarser grain fraction (4-0.063 mm, wet sieving); a Cilas 1064 laser diffraction granulometer was used for the analysis of the finer fraction $(0.0004-0.5 \mathrm{~mm})$. Ultrasonic dispersion, distillate water and washing in sodium polyphosphate, were used prior to analysis in order to avoid flocculation of the analysed particles. The average grain size is demonstrated by the graphic mean $(\mathrm{Mz})$ and the uniformity of the grain size distribution/sorting by the standard deviation ( $\sigma \mathrm{l})$ (Folk and Ward, 1957).

The results of the provenance analysis are based on a combination of pebble analysis, evaluation of thin-sections (10 samples) and heavy mineral studies. Pebble and cobble petrography, shape and roundness were determined in two borehole cores (clasts larger than $8 \mathrm{~mm}$ ). Shape and roundness were estimated visually using the methods of Zingg (1935) and Powers (1982). Heavy minerals were quantified through a counting method (mod. \%) under a polarizing microscope in the grain-size fraction $0.063-0.125 \mathrm{~mm}$ ( 14 analyses). The opaque minerals were not considered in the calculation. Several samples of bedrock greywackes were also evaluated. The mineral compositions of selected heavy minerals were determined using a Cameca SX100 electron microprobe at the Joint Laboratory of Electron Microscopy and Microanalysis of Masaryk University and the Czech Geological Survey Brno (operator P. Gadas). Data from 46 analysed garnet grains from core samples were available. Results from further garnets (120 grains) from the near surroundings provide additional information.

The gamma-ray spectra (GRS) were measured by a GR-320 enviSPEC laboratory spectrometer with a $3 \times 3$ in. $\mathrm{Nal}(\mathrm{TI})$ scintillation detector (Exploranium, Canada). Counts per second in selected energy windows were directly converted to concentrations of $\mathrm{K}(\%), \mathrm{U}(\mathrm{ppm})$ and Th (ppm). One measurement of 30-minutes was performed for each measured sample (73 samples - min. $300 \mathrm{~g}$ ). The total radioactivity i.e. "standard gamma ray" was labelled as SGR and was estimated from the following relationship: SGR $[\mathrm{API}]=16.32 \times \mathrm{K}(\%)+$ $8.09 \times \mathrm{U}(\mathrm{ppm})+3.93 \times \mathrm{Th}(\mathrm{ppm})(\mathrm{API} /$ American Petroleum Institute units) (Rider, 1996).

For palaeontological studies, 14 samples were soaked in warm water with sodium carbonate for disaggregation, and then washed under running water through $0.063 \mathrm{~mm}$ mesh sieves. Foraminifers were picked and determined using the binocular microscope Nikon.

New shallow seismic reflection survey on the profiles P9-3 and P9-4 (see Figs. 1B and 2) was implemented using Terraloc Mk-6 system with 24 geophones. The distance of geophones was $4 \mathrm{~m}$ and as energy source the heavy hammer was used. To obtain a sufficiently strong signal the $3-10$ multiple records were acquired at each point and then stacked. Shot point distance was also $4 \mathrm{~m}$, offset $28 \mathrm{~m}$. Data was processed using ReflexW software (Sandmeier, 2000). The summation process of several traces of CDP (common depth point) increases the ratio signal/noise. The time-to-depth conversion for shallow re- flection seismic is computed after Baker (1999), in our case the interval velocity of $2100 \mathrm{~m} / \mathrm{s}$ was used (after seismic well-logging in borehole $\mathrm{BL}-1$ ).

\section{RESULTS}

\section{FACIES ANALYSIS}

Sedimentological study of the preserved cores of boreholes 2212_B and 2212_W led to the distinction of 16 lithofacies. Detailed descriptions (lithology, stratification and sedimentary structures) and interpretation of each facies are given in Table 1. The examples of lithofacies can be followed in Figures 4 and 5. Five facies associations (FA) were identified corresponding to the principal depositional environments. Logs illustrating the distribution of facies and facies associations within boreholes are presented in Figure 6A, B. FA are described from bottom to top, i.e. from the oldest to the youngest. Although the facies associations are labelled with their interpretative names, the description and interpretation are separated.

\section{FA 1 - COLLUVIAL DEPOSITS TO DEPOSITS} OF ALLUVIAL FAN

This facies association constitutes the lowermost and the smallest part of the studied succession (292.5 up to $283.3 \mathrm{~m}$ i.e. $9.2 \mathrm{~m}$ thick, volumetrically $3.8 \%$ ). Deposits of FA 1 mantle the pre-Neogene basement with an irregular unconformity surface and are covered by deposits of FA 2 (see Fig. 6A). FA1 is formed mostly by very thickly bedded (1.0-3.4 m thick) poorly sorted breccias of facies GB (Fig. 4A) and gravels of facies Gc (Fig. 4C). The occurrence of facies $\mathrm{Gm}$ (Fig. 4B) is less common.

The deposition of FA 1 starts with a more than $3 \mathrm{~m}$ thick package of facies Gc. These structureless pebbly conglomerates are typified by a various content of angular, subangular and rounded clasts and by a clast supported fabric. The occurrence of beds of angular breccia of facies GB is significant for FA 1. The composition of the pebble grade, angular to subangular clasts is represented by Early Carboniferous clastic rocks ("Culmian facies") i.e. greywackes and shales, generally similar to the rocks in the underlying basement. The poorly sorted, matrix-supported conglomerate of facies $\mathrm{Gm}$ forms a subhorizontal package about $m$ thick interbedded within the $G_{c}$ and GB facies. Beds of facies GB, Gc and Gm have sharp irregular bases typified by a significant grain-size contrast. Clasts reveal a highly disorganised fabric. The deposits of FA 1 are devoid of fossils.

Interpretation: the poorly sorted thickly-bedded coarse-grained deposits of FA 1 give evidence of massflow transport and palaeoslope. Clasts of facies GB are directly derived from weathered local palaeotopographic highs. Facies GB is interpreted as talus breccia. Deposits of $\mathrm{Gc}_{\mathrm{c}}$ and $\mathrm{Gm}$ represent subaerial debris flows (Nemec and Steel, 1984). The fine-grained (mostly sandstone grade) matrix of the dominant clast supported conglomerates/breccias might be partly trapped in the coarse grained framework. FA 1 is interpreted as subaerial colluvial to alluvial fan deposit. The evidence of bedding, alternations of lithofacies and sharp bedding surfaces might point to some role of hydraulic reworking by water flows (Nemec and Kazanci, 1999). The alternation of breccias with conglomerates indicates that the weathering and talus slope development was contemporaneous with the early stages of alluvial fan sedimentation (Went, 2005; Breda et al., 2007). A mantle of weathered and partly reworked debris was resting on an upper fan seg- 
Descriptive summary list of lithofacies of the studied deposits distinguished in the boreholes 2212_B Odry and 2212_W Odry

\begin{tabular}{|c|c|}
\hline Facies & Description \\
\hline GB & $\begin{array}{l}\text { Clast-supported disorganised breccia. Poorly sorted, polymodal, clast to matrix sup- } \\
\text { ported. Angular to subangular clasts (pebble size dominates, cobble size significantly less } \\
\text { common) are mostly greywackes and shales. Max. clast reaches } 16 \mathrm{~cm} \text { (A axis). Matrix is } \\
\text { represented by coarse to very coarse sand. }\end{array}$ \\
\hline Gc & $\begin{array}{l}\text { Clast-supported or clast- to matrix-supported pebble conglomerate. Poorly sorted, massive, } \\
\text { polymodal. Matrix is formed by coarse to very coarse sand. Pebbles are dominated by } \\
\text { greywackes and shales, mostly subrounded to subangular. Proportion of rounded to sub- } \\
\text { rounded pebbles increases towards the top of succession. The largest cobbles reach } 15 \mathrm{~cm} \\
\text { (A axis). Rare outsized intraclasts (pebble to cobble size) are represented by slate coal or } \\
\text { poorly sorted sandstone (facies Smg). Mostly disorganized fabric, however, some elon- } \\
\text { gated or bladed pebbles reveal clast fabric of } \mathrm{A}(\mathrm{p}) \text { type. Sharp mostly nonerosional flat } \\
\text { bases and tops of beds. }\end{array}$ \\
\hline $\mathrm{Gm}$ & $\begin{array}{l}\text { Matrix-supported or matrix- to clast-supported granule to medium pebble conglomerate. } \\
\text { Matrix is formed by poorly sorted muddy sand. Structureless. Clasts are mostly } \\
\text { subangular and randomly scattered. Angular and subrounded clasts less common. Sharp } \\
\text { relatively flat base and top of beds. Bed thickness ranges from } 25 \text { to } 225 \mathrm{~cm} \text {. }\end{array}$ \\
\hline Go & $\begin{array}{l}\text { Isolated outsized clasts, beds one clast thick. Mostly shales or wackes. Boulders are } \\
\text { larger than the diameter of the core. Clasts are mostly angular to subangular. Pebbles or } \\
\text { cobbles of slaty coal and/or pebbly sandstone (intraclasts?) are significantly smaller (up to } \\
8 \mathrm{~cm} \text { in diameter) and often subrounded. }\end{array}$ \\
\hline $\mathrm{Gi}$ & $\begin{array}{l}\text { Clast-supported conglomerate (locally openwork fabric). Coarse tail inverse grading or } \\
\text { distributional inverse grading. The largest clasts reach } 4 \mathrm{~cm} \text { in A axis. Elongated or bladed } \\
\text { pebbles commonly reveal clast fabric of } A(p) \text { type. Matrix is formed by coarse sand. Sharp } \\
\text { non-erosional, relatively flat base and top of beds. Bed thickness ranges from } 5 \text { to } 25 \mathrm{~cm} \text {. } \\
\text { Bed with coarse-tail grading are generally thicker than beds with distributional grading. } \\
\text { Sometimes evident inclined bedding. }\end{array}$ \\
\hline
\end{tabular}

Gravelite to pebbly sandstone. Distributional normal grading above the base (not always

$\mathrm{Gg} \quad \begin{aligned} & \text { preserved layer) followed by layer of massive sandstone and even layer of sandstone with } \\ & \text { planar lamination. The thickness of individual layers is about } 5-10 \mathrm{~cm} \text {. Sharp flat base of }\end{aligned}$ planar lamination. The thickness of individual layers is about $5-10 \mathrm{~cm}$. Sharp flat base of
beds, sometime with scattered pebbles up to $3.5 \mathrm{~cm}$ in diameter. Locally evident inclined bedding. Gw $\quad$ Clast-supported pebbly conglomerate. Matrix formed by coarse to medium grained sand. $A(p)$ type is typical. Crude planar stratification.

Very coarse to coarse sandstone with admixture of granules and isolated medium pebbles

Sgm (up to $1.5 \mathrm{~cm}$ in diameter, mostly subrounded). Massive, or poorly defined inclined planar stratification. Elongated pebbles commonly reveal $A(p)$ type of fabric. Sharp inclined tops and bases of beds. Bed thickness varies between 5 and $50 \mathrm{~cm}$. Flat nonerosive base and top.

Very coarse, coarse, coarse to medium grained sandstone poorly sorted. Inclined planar $5 \mathrm{~cm}$ thick, coset are $40-50 \mathrm{~cm}$ thick. Rare scattered granules or small pebbles (up to $1 \mathrm{~cm}$
$\mathrm{cos}$ in diameter). Clast fabric of $A(p)$ type, parallel to bedding.

Very coarse, coarse, coarse to medium grained sandstone poorly sorted. Planar stratification, horizontal to subhorizontal. Beds reveal sharp flat base and top. Subfacies SI 1 (rare scattered granules or small pebbles (up to $1 \mathrm{~cm}$ in diameter) was recognized in association with facies Gms. Subfacies SI 2 (scattered shell debris and small intraclasts of shiny coal or lamina of coalified organic matter) was recognized in association with lithofacies $\mathrm{Sm}$ and SII.

Sm $\quad$ Very coarse sand to sandstone, relatively well-sorted, variable admixture of granules and continuous laminas of black shiny coal. Massive.

Fine to medium-grained sand to sandstone or silty sand, plane parallel lamination with low angle of inclination. Well sorted. Micaceous. Sporadic bioturbation. $\mathrm{Mz}=2.8-3.3 \Phi$, $\sigma_{l}=1.9-2.2 \Phi$

Rhythmic alternation of slightly irregular laminae of very fine sandy silt or silty sand with laminae or thin beds of silty clay. Different content of coalified plant detritus between clay and silt laminae. Lithification variable. Bed thickness $2-35 \mathrm{~cm}$. Sharp base and top of beds. Low bioturbation, mostly subhorizontal tunnels about $5 \mathrm{~mm}$ in diameter filled by very fine sand. Content of clay varies between 17 and $25.6 \%$, content of silt ranges $78.8-82.3 \%$, and very fine sand constitutes 0.5 to $1.8 \% . \mathrm{Mz}=9.9-15.6 \Phi$.

Clayey silt, well-sorted, planar parallel lamination. Sharp base and top of beds. Bed thickness $35 \mathrm{~cm}$. Rare plant fragments and mollusc shells. Scattered laminas of fine to very fine sand. Content of clay varies between 15.6 and $23 \%$, content of silt 77 to $84.3 \%$, and very fine sand 0 to $0.8 \% . \mathrm{Mz}=9.6-15.1 \Phi$.

Massive to faintly laminated clayey silt. Rare thin laminae of very fine sandstone. Intensity of bioturbation highly variable. Irregularly distributed coalified plant detritus, scattered grains of very fine sand. Rare occurrence of mollusc shell fragments. Content of clay varies between 15.7 and $22.6 \%$, content of silt 76.4 to $84.1 \%$, and very fine sand 0 to $7.5 \%$. $\mathrm{Mz}=10.5-16.6 \Phi$.

Massive to faintly laminated clayey silt, irregular distribution of fine to very fine sand. Irregularly distributed coalified plant detritus. Content of clay varies between 17.6 and $21.2 \%$, content of silt 78.6 to $82.2 \%$, and very fine sand 0 to $2.5 \% . \mathrm{Mz}=10.0-14.9 \Phi$. Mass flow deposits of talus, scree
slopes mantling by basement clasts (Went, 2005).

Cohesionless debris flows (Pierson, 1981; Nemec and Steel, 1984).

Cohesionless to cohesive debris flows (Nemec, 1990).

Deposition by rock fall to debris fall (Nemec, 1990), or modified beds by erosional stripping of overpassing flows and currents (Gobo et al., 2015)

Cohesionless debris flows with frictional shear regime (Gobo et al. 2015), rapid deposition from high-concentrated gravelly dispersion undergoing high shear strain and clast collision (Sohn et al., 2002).

Deposition of high-density turbidity Deposition of high-density turbidity
current surges (sensu Lowe, 1982) or pulsating hyperpycnal flows. Submarine delta slopes.

High-density, sandy debris flows (Hwang and Chough, 2000) or high-density turbidity currents (Lowe, 1982). Submarine delta slopes.

Deposition by high-density turbidity current (sensu Lowe, 1982) or hyperconcentrated density flows (Mulder and Alexander, 2001).

Tractional deposition by low density turbidity current (sensu Lowe, 1982) or spaced planar-lamination (sensu Taling et al., 2012).

Reworked fan sediments (abandoned fan sectors; Went 2005), tractional deposits on mouth-bar slope by fric-
tional high-stage river effluent tional high-stage river effluer
(Wright, 1977; Gobo et al., 2014).

Rapid deposition from suspension (nearshore deposits - Hwang and Chough, 2000).

Deposition by fair-weather waves on delta beachface (Bluck, 2010).

Deposition from suspension and from traction currents (distal turbidites, distal tempestites). Highly variable sedimentation rate, oxygenated bottom, bioturbation reworking. Open marine setting.

Slow settling both from traction (wanning flow) and suspension, periodic sediment supply(?), open marine deposits (Hwang and Chough, 2000).

Open marine deposits of suspension fallout and/or deposition affected by river-derived hypopycnal plumes (?) (Nemec, 1995). Bottom colonisation.

Open marine suspension deposits, partly connected with river-derived hypopycnal suspension plumes? (Nemec, 1995). 

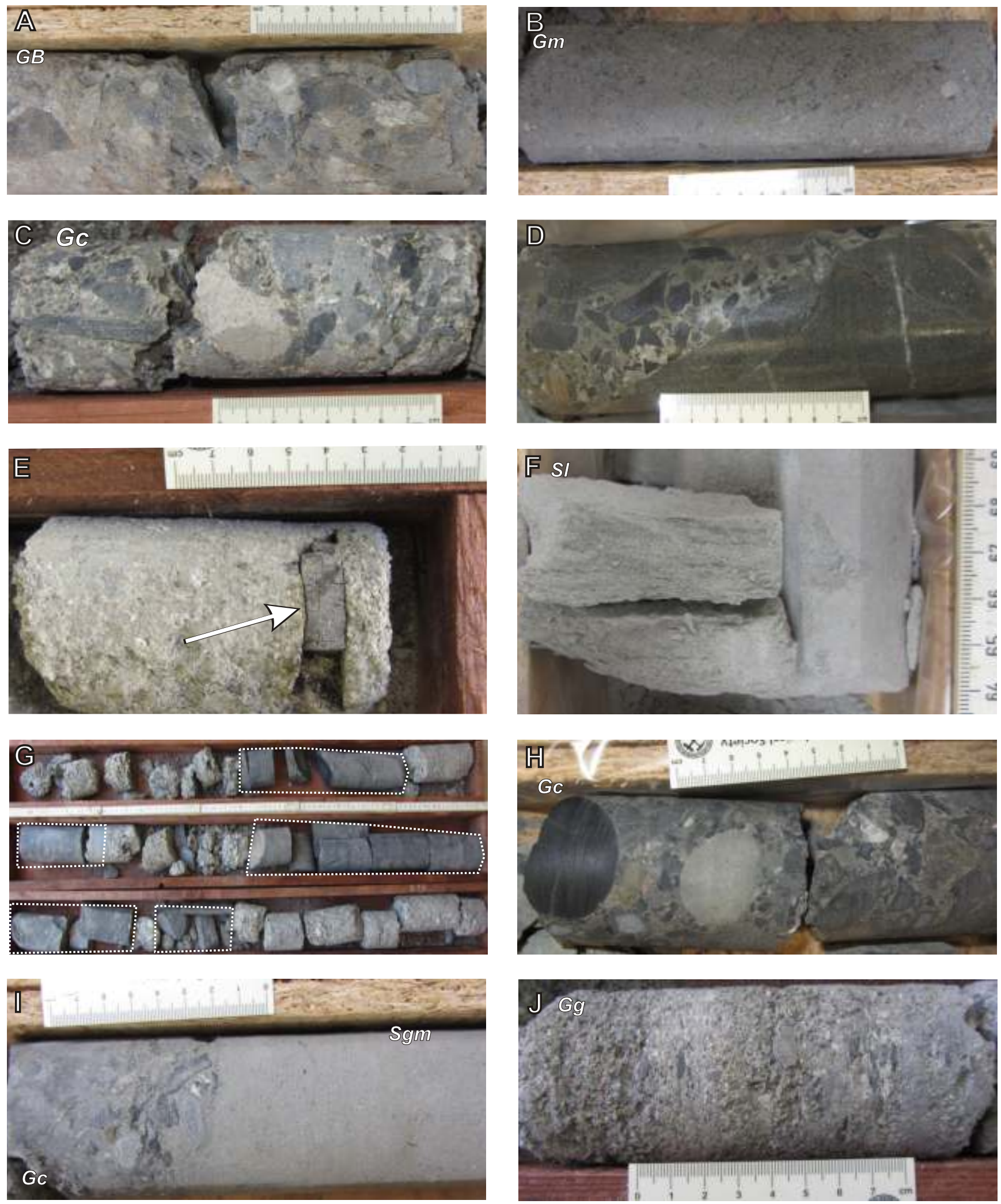

Fig. 4. Selected examples of recognised lithofacies

A - facies GB; $\mathbf{B}$ - facies Gm, C - facies Gm, D - infill of subvertical cracks within the pre-Neogene Culmian basement, $\mathbf{E}$-coal intraclasts in the low stage of disintegration (white arrow), $\mathbf{F}$ - facies $\mathrm{SI}, \mathbf{G}$ - alternation of facies Gc and Go; large boulders and blocks of facies Go are encircled by white dots, $\mathbf{H}$ - facies Gc; I - sharp contact of facies Gc and Sgm; J - facies Gg 

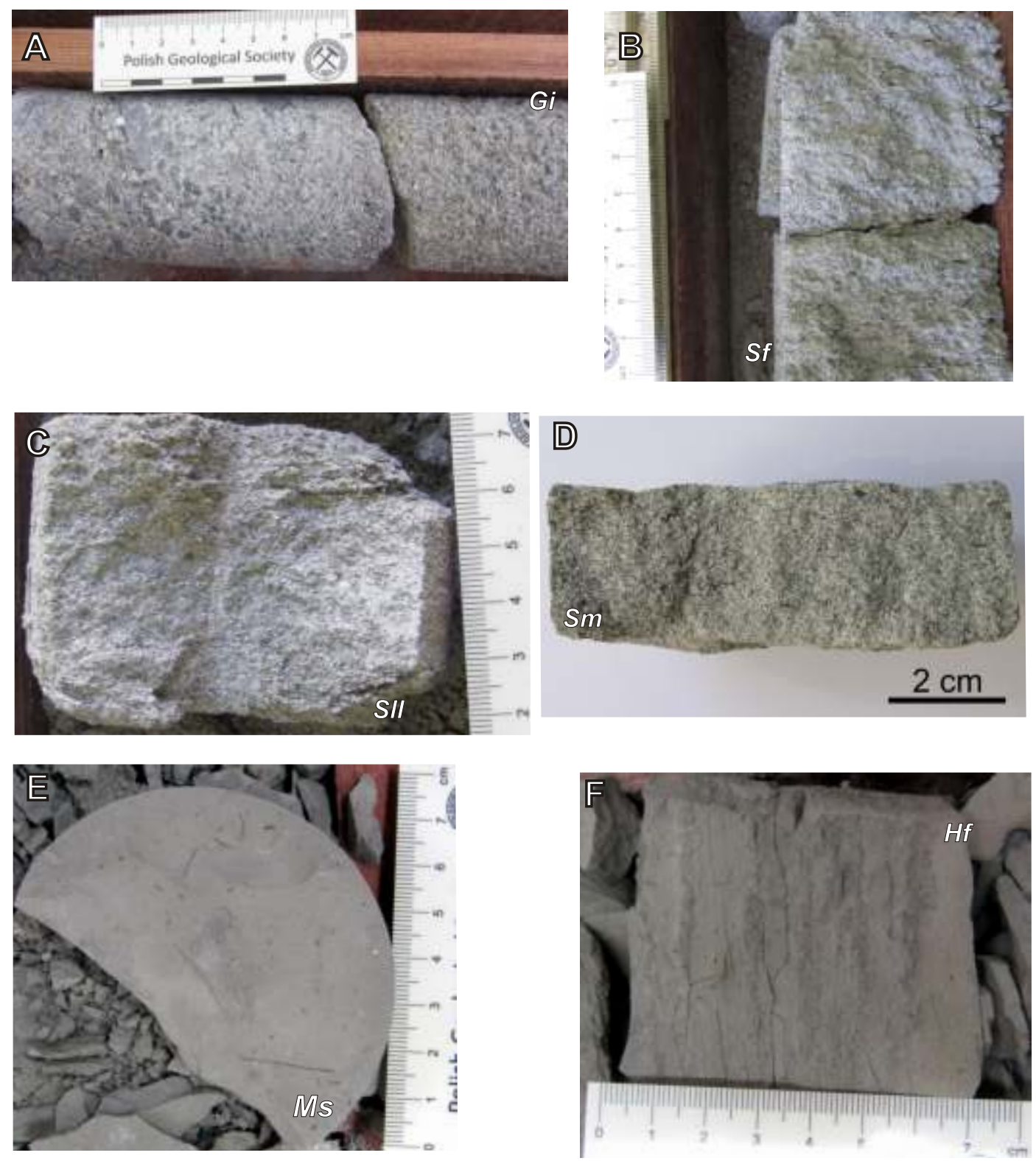

Fig. 5. Selected examples of recognised lithofacies

A - facies Gi, B - facies Sf, C- facies SII, D - facies Sm, E - facies Ms, F - facies Hf

ment and further transported downslope by gravity. However, this alternation might also point to differences in provenance/i.e. multipoint sources (Hwang and Chough, 2000). Dominant angular clasts originated from nearby Culmian greywackes and shales. The rounded pebbles were sourced either from more distant Culmian conglomerates (relatively less common than greywackes and shales in the bedrock) or from younger sedimentary cover of the basement. The preservation of FA 1 at the base of the Neogene succession and its transition to deposits of alluvial fan (FA 2) points to a proximal fan location.

Highly irregular subvertical interbeds or veins of facies GB or Gc, maximally few dm thick, were recognized also within the Culmian bedrock, where they form an infill of irregular cracks (Fig. 4D). The fresh appearance of angular clasts and sharp contacts with fresh bedrock reveal the relative rapid filling of these cracks and dominance of physical weathering processes. Both the matrix- and clast-supported fabric of these interbeds or veins show that some of might represent clastic dikes.
FA 2 - DEPOSITS OF ALLUVIAL FAN

The facies association FA 2 represents the volumetrically predominant part of the Miocene succession (68\%) and was recognized in two packages. FA 2 is at first developed between 232.0 up to $283.3 \mathrm{~m}$ where it covers the deposits of FA 1 and is covered by FA 3 . FA 2 is further developed between 80 and $217 \mathrm{~m}$, where it overlies the deposits of $\mathrm{FA} 3$ and is overlain by FA 4 (see Fig. 6A). The topmost part (datum 80-83 m) of FA 2 was not documented by cores and was identified according the wire-line logs (see Fig. 7).

Very thickly to thickly bedded (0.3-9.9 m thick), poorly sorted gravels of facies Gc (Fig. $4 \mathrm{H}$ ) strongly dominate in the FA $2(77.7 \%)$. The coarse-grained lithology of FA 2 is further confirmed by occurrences of facies $\mathrm{Gm}(8.1 \%)$, Go (Fig. 4G; $3.3 \%$ ) and $\mathrm{Gg}$ (Fig. 4J; 0.6\%). While the deposits of facies $\mathrm{Gm}$ are very thickly bedded, the deposits of facies Go and $\mathrm{Gg}$ are thinly bedded. Thinly to thickly bedded pebbly sandstones of fa- 
cies Sgm (Fig. 4I) are less common (5.3\%) similarly to stratified sandstones of facies SI (Fig. 4F; 5.0\%). Amalgamated beds of lithofacies $\mathrm{Gc}, \mathrm{Gm}$ or Sgm are interrupted by several $\mathrm{cm}$ to $\mathrm{dm}$ thick interbeds of lithofacies Go. Facies SI mostly occur as thin interbeds within a monotonous package of Gc. The maximal size of clasts of Go is difficult to define precisely in borehole cores, but the boulder class is highly probable (see Fig. 4G). Pebbles of facies Gc, Gm, Go, Gg and Sgm are mostly subangular to subrounded and the proportion of rounded to subrounded pebbles generally increases upward in the succession (compare Fig. 4C, H). Similarly slightly broader pebble spectra were recognized in the upper part of FA 2 compared to the lower one (see chapter 5 ) with occurrence of coal intraclasts of pebble size (Fig. 4E).

Several fining upward (FU) units (tens of $m$ thick) could be recognized within the lower portion (up to the datum of $180 \mathrm{~m}$ ) of the FA 2, both on the funnel shaped wireline log pattern (Fig. 7) and facies succession. They are marked by vertical changes in the maximum grain size, mean grain size, and in bed thickness. The lower parts of the FU units is represented mostly by $\mathrm{Gc}$ and the upper part mostly by Sgm deposits. The upper portion (above the datum 180 m) of FA 2 succession reveals generally a blocky but serrated pattern of the wireline log.

Beds of facies Gc, Sgm and Gm have sharp flat or irregular bases and tops typified by significant grain-size change. Their bases and tops are non-erosive, but also erosive. The tops and bases of Go beds are nonerosive. The base of FA 2 succession is rather arbitrary connected with relatively higher textural maturity of coarse clasts and deposition of a medium to thickly-bedded package of matrix-dominated $\mathrm{Gm}$.

Both packages of FA 2 are devoid of fossil. However, two intraclasts from the upper FA 2 package provide some micropalaeontological evidence. A fish tooth, fragment of mollusc, pyrite, and agglutinated foraminifers (Eggenburgian age?) were documented in the sample from a depth of $180.4 \mathrm{~m}$. In the sample from the depth of 201.83 m only a fish tooth was found.

Interpretation: The thick bedding, poorly organized texture with clast- to matrix-supported conglomerates, mostly disorganised fabric (with some vertical clasts) and general lack of stratification point to a dominant non-selective, en-masse style of deposition from flows of high sediment concentration and common clast interactions (sensu Nemec and Steel, 1984; Went, 2005). The locally developed sub-horizontal orientation of pebbles/ $A(p)$ is interpreted as reflecting strongly sheared flows (sensu Lowe, 1982; Maejima, 1988; Nemec, 1990), whereas the lack of it implies flows which have not experienced pervasive intense shearing (sensu Marzo and Anadón, 1988). Dominant $\mathrm{Gc}$, Sgm and $\mathrm{Gg}$ are commonly attributed to non-cohesive sediment debris flows (sensu Lowe, 1982) or hyperconcentrated flows (sensu Benvenuti, 2003). The amount of mud in facies Gc varies between 9.6 to $10.2 \%$ and sand fraction comprises 27 to $45 \%$. Although mud was mostly composed of silt fraction, some role of cohesive strength can be supposed (sensu Talling et al., 2012). Matrix rich beds of Gm exhibit characteristics typical of classical debris flows (sensu Blair and McPherson, 1995). The presence of gravel clasts floating in the matrix points to a flow with some cohesive strength and/or shearing flow properties (Lowe, 1982). Subordinate thin beds of stratified sandstones SI within debris flows $\mathrm{Gc}$, on the other hand, suggest an episodic deposition of relatively shallow but powerful stream-flows following debris flow deposition (sensu Marzo and Anadón, 1988; Went, 2005). Such a condition might reveal the existence of sandflats at the fan toe (sensu Hubert and Hyde, 1982). The role of water (or phases of the more turbulent flows) is further confined by some sharp, undulated erosive bases of beds. Deposits of Go are interpreted as rock/debris fall deposits (sensu Nemec, 1990), although they can represent "isolated megaclasts" or coarse gravel concentrated through fine-fraction winnowing of the successive overpassing sediment-deficient water flows (sensu Nemec and Steel, 1984; Blair, 1999).

FA 2 is interpreted as subaerial deposits of alluvial fan, which is consistent with the assemblage of stream-flow deposits and debris-flow conglomerates (Rust, 1978). The dominant debris-flows could have originated due to the rapid deceleration of heavily sediment-laden stream-floods (Nemec and Steel, 1984) as these spread on the fan surface. The dominance of amalgamated very thick, coarse-grained beds (Gc, Gm, Go debris-flow or debris fall conglomerates) may suggest deposition in the proximal part of an alluvial fan. In a down-fan direction (i.e. basinward), these proximal facies become less common and "monolithic" and are progressively replaced by thinly bedded and finer grained deposits (i.e. facies Sgm) with more common facies alternation (Marzo and Anadón, 1988). The meagre sorting is connected with flashy discharge. The fan surface reworking might occur during recessional flood stage or during the long intervals between major flash floods (sensu Blair, 1999). Channelling was not recognized, although this may be due to limited core extent and coarse-grained nature or reflect the form of sheetfloods or less fluidised flows. Coal fragments reveal humid conditions and originate probably from distal source area or abandoned fan lobes (sensu Fernández et al., 1988).

As the alluvial fan grew sufficiently large, it buried the deposits of FA 1. Repetitive FU units of FA 2 succession are interpreted as reflecting successive fan prograding-retreating episodes. The blocky shaped upper portion of FA 2 is interpreted as aggrading proximal fan.

FA 3 - DEPOSITS OF SUBAQUEOUS ALLUVIAL FAN/FAN-DELTA DEPOSITS

The facies association FA 3 both overlies and is overlain by deposits of FA 2 (see Fig. 6A). FA 3 was distinguished from FA 2 by its finer grade, thinner and partly inclined bedding, significant occurrence of stratification and grain-size grading, better sorting and common organized pebble fabric. FA 3 represents volumetrically a subordinate part of the Miocene succession (5.4\%), being recognized between 217 and $232 \mathrm{~m}$.

The predominant proportion of FA 3 is composed of medium to thickly bedded $(0.1-0.7 \mathrm{~m})$ pebbly conglomerates of lithofacies Gw (38.8\%) and Gi (Fig. 5A; 28.9\%). Sets of inversely graded conglomerates beds $\mathrm{Gi}$ are 0.1 to $0.2 \mathrm{~m}$ thick, cosets reach $0.7 \mathrm{~m}$. Inverse grading is developed in the entire set thickness. Slightly less common are thinly to medium bedded (0.1-0.5 m) sandstones of lithofacies Sf (Fig. 5B; 13.2\%) and normally graded conglomerates of $\mathrm{Gg}(12.5 \%)$. Other thinly bedded lithofacies (Go, Gc) are only accessory (1.3 and $2.5 \%$ ). Pebbles of conglomeratic facies are mostly subrounded though, both rounded and subangular clasts are also present. Common is a well-developed $A(p)$ fabric when the flatter clasts lie with their maximum projection planes parallel to the bedding. Pebbles are moderately sorted, with dominant grain-size grade of coarse to very coarse pebbles $(2-5 \mathrm{~cm}$ - along the A axis). Matrix is formed by medium to coarse grain sand. It is notable that gravel and sand fraction are better separated here than in FA 2. Outsized clasts are absent (except Go) similarly as matrix of muddy sand. Beds have both erosional and nonerosional sharp boundaries, commonly inclined. Inclined planar parallel stratification (facies $\mathrm{Sf}$ ) is highlighted by minor vertical changes in clast sizes between adjacent strata (commonly only one clast thick) and is highlighted by a plane-parallel clast orientation. The deposits of FA 3 are devoid of fossils. 

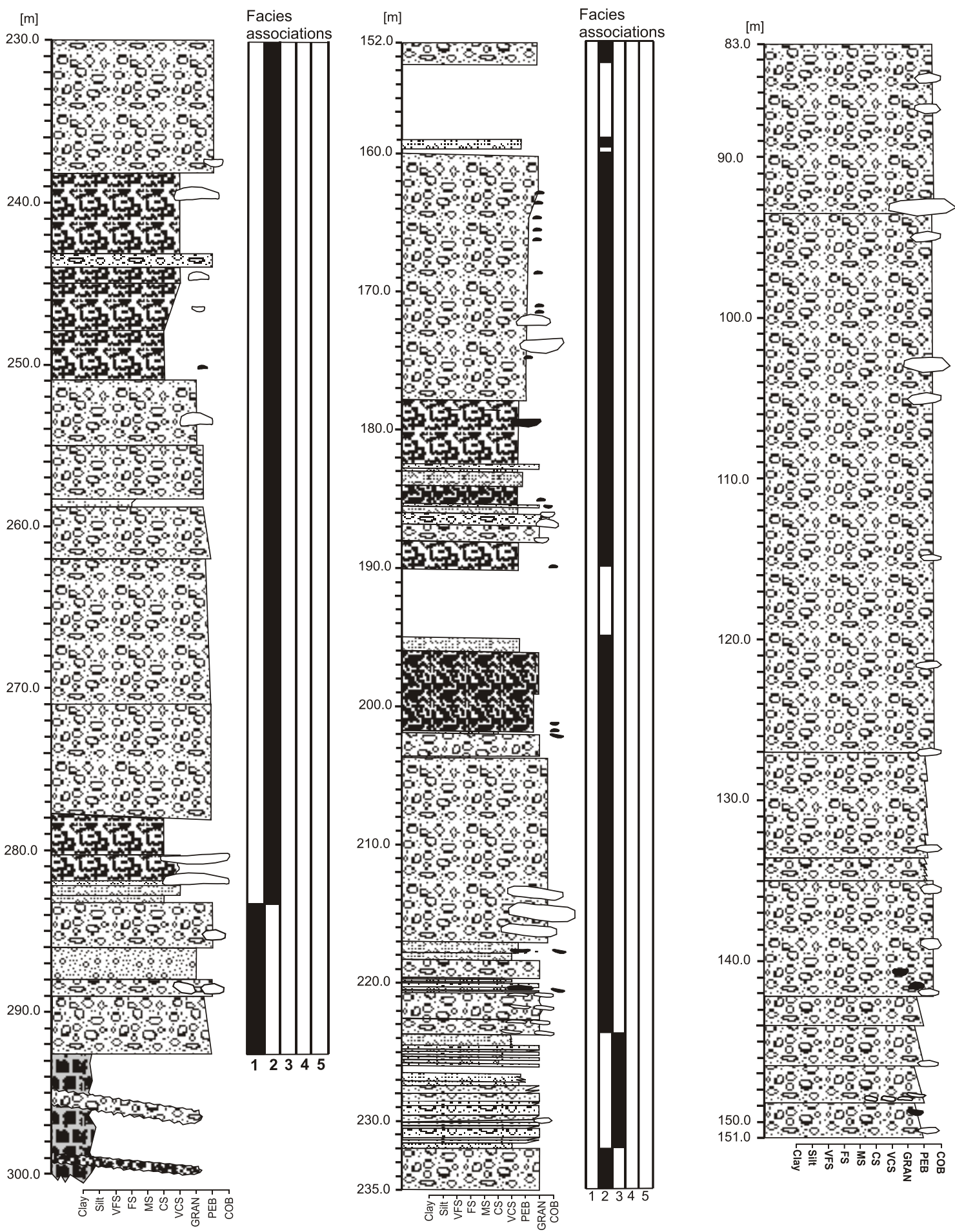

Facies
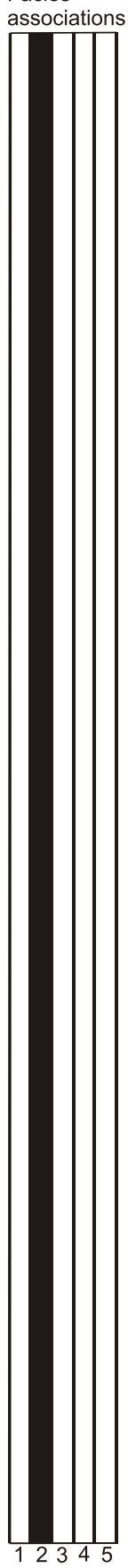

Fig. 6. Sedimentological core logs

A-lower portion of the sedimentary succession; B - upper portion of the sedimentary succession with results of spectral gamma-ray 

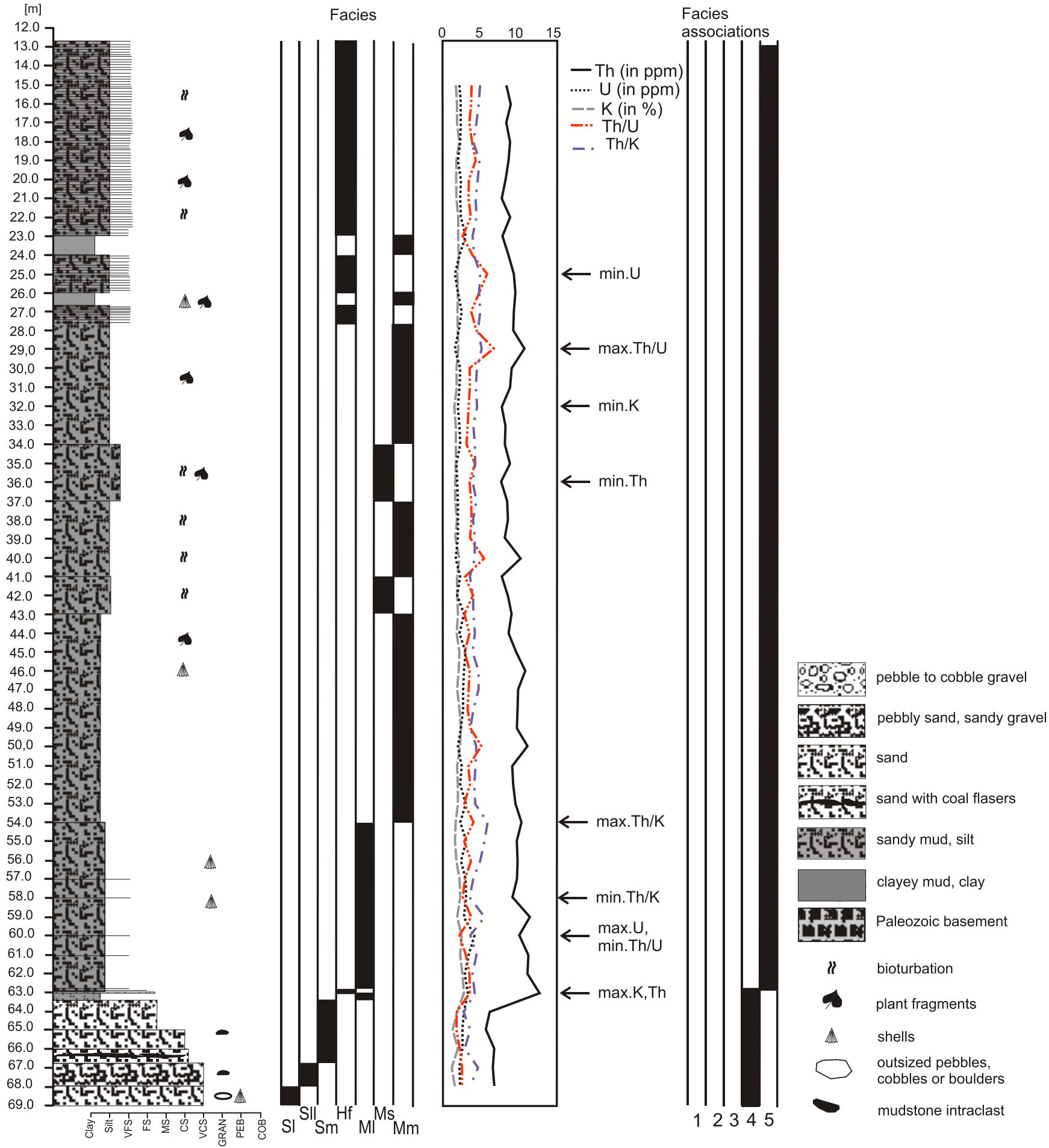

of the boreholes 2212_B and 2212_W

analysis; the logs show the stratigraphic distribution of facies associations (FA1-5) and partly also facies distribution (FA 5) 


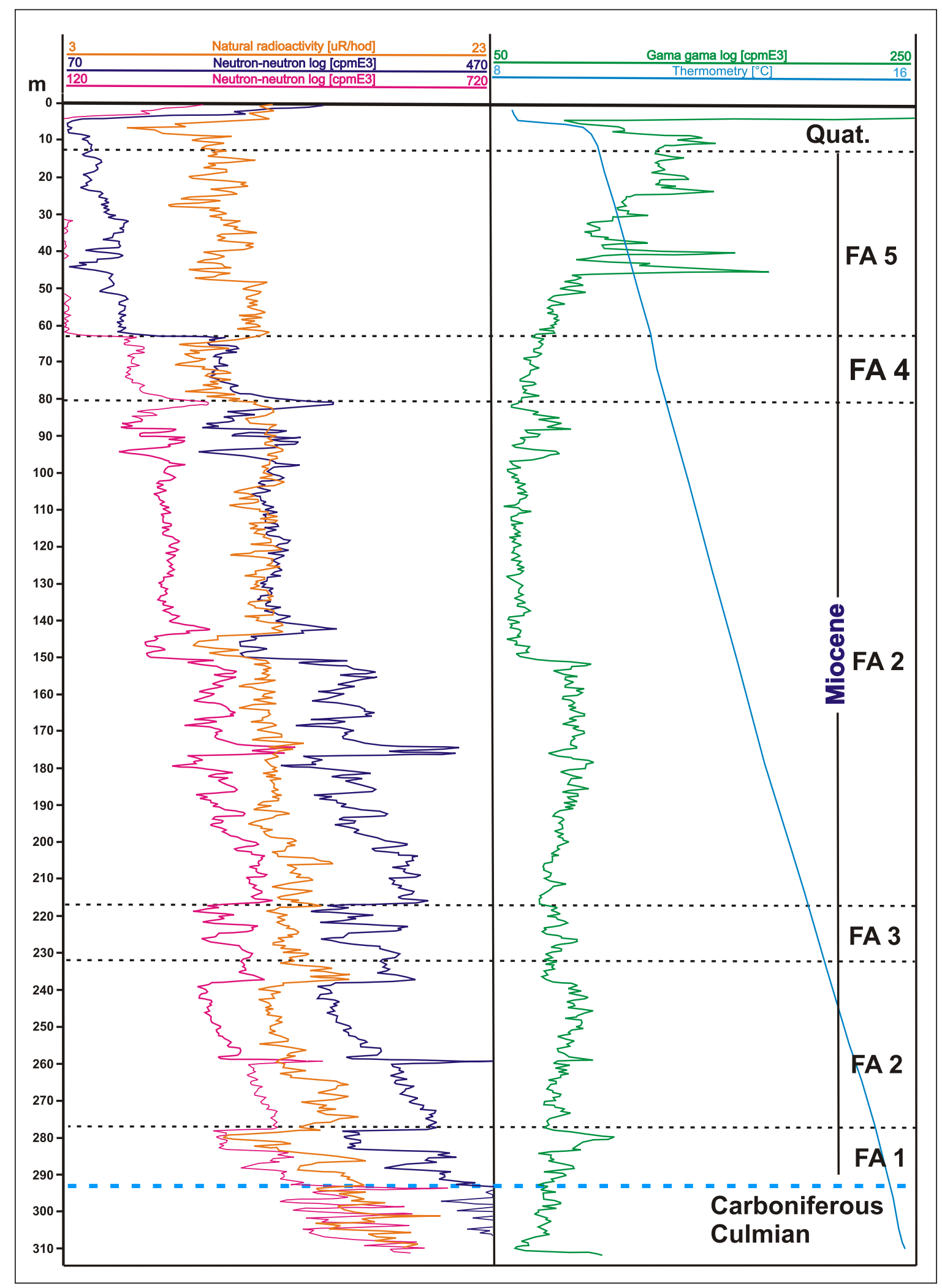

Fig. 7. Wireline logs of the sedimentary succession of the borehole 2212_W Odry

Notice the funnel shaped wireline log pattern in the lower and upper portion of the succession and generally blocky but serrated pattern in the middle portion (above the datum $180 \mathrm{~m}$ ) 
Interpretation: facies $\mathrm{Gw}, \mathrm{Gi}, \mathrm{Gc}$ and $\mathrm{Gg}$ are interpreted as gravity flows deposits: debris flows, high density turbidity currents and density-modified grain-flows of Lowe (1982), or hyperconcentrated flows of Benvenuti (2003). Variations in preserved structures refer to variations in clast supporting processes (sensu Nemec and Steel, 1984). The sub-horizontal orientation and imbrication of clasts are interpreted as reflecting floods with strongly sheared flows of high sediment concentration and common clast interactions (sensu Rees, 1968). The repetitive facies successions Gc-Sf, Gi-Gw and Gf-Sf result from flow transformations (sensu Sohn, 2000; Benvenuti, 2003). Facies Gw is interpreted as a deposit of a waning stage of flow (or flow body) capping the cohesionless debris flow (flow head) $\mathrm{Gi}, \mathrm{Gc}$ beneath. Deposits of Sf are tractional deposits (flow tail?). Thin bedding, common grading, stratification, better sorting, and rounding of pebbles, pebble fabric are all features which are more commonly encountered in sub-aqueous debris flows than in sub-aerial ones (sensu Nemec and Steel, 1984; Maejima, 1988). Inclined bedding and stratification is commonly associated with foreset beds and migration of coarse grained dune bedforms (cf. Gilbert type deltas).

Deposits of FA 3 were formed by subaqueous sediment gravity flows, implying the development of a fan-delta front and/or slope. Dominance of subrounded to rounded (better rounded than in FA 2), with common alignment of pebbles and cobbles parallel to the bed boundaries is common for delta-slope conglomerates (Maejima, 1988). It reflects the situation when gravels were delivered by gravity or water flows to the fan-delta front, and hence experienced a variable degree of clast-size pre-sorting and reworking before eventually becoming subject to the subaqueous emplacement of mass-flow (sensu Wescott and Ethridge, 1982; Marzo and Anadón, 1988).

The fan-delta was formed at the interface between the active fan and a standing body of water (Nemec and Steel, 1988). Overloading and slope instability due to rapid, almost continuous sediment accumulation or by catastrophic floods, probably caused failure of water saturated sediment and subsequent subaqueous gravity transport i.e. mass flow dominated delta slope (Maejima, 1988). Whereas most of the coarse-grained sediment was trapped on the delta suspended mud was carried either by surface plumes or by gravity flows, bypassed the valley and supplied the adjacent basin (oriented perpendicular to the pallaeovalley). The formation of a Gilbert-type delta requires:

- a voluminous coarse-grained sediment supply into a protected or low-energy basin or embayment, laterally confined by topographic highs (Collela et al., 1987),

- steep, often fault-controlled, nearshore slopes necessary to promote the development of large-scale foresets (Collela et al., 1987),

- a period of sea level stillstand (Postma and Roep, 1985). FA 4 - NEARSHORE DEPOSITS
(WITH A SHALLOW WATER DELTA?)

The facies association comprises the upper part of the studied succession (ranging from 63.4 to $80.0 \mathrm{~m}$ ) and volumetrically constitutes $6.9 \%$ thereof. Significant proportion (an interval 69 to $80 \mathrm{~m}$ ) of FA 4 was not documented by a complete core and only two isolated samples formed by lithofacies $\mathrm{Ml}$ were available (72.4-73.0 $\mathrm{m}$ and 74.0-75.5 m; see Fig. 6B). The lower FA boundary was identified according the wire-line logs (see Fig. 7).

FA 4 consists of five lithofacies (SII, SI, Sm, $\mathrm{Hf}$ and MI) with overall FU arrangement observed especially in the cored interval 63.4-69.0 m. Laminated medium to fine sand and sand- stones of facies SII (Fig. 5C) dominate in this interval (54.2\%) followed by Sm (20.3\%; Fig. 5D) and SI (17\%). Sands of facies Sll seem to be relatively well-sorted, although $\sigma_{\mid}$varies between 1.9-2.2Ф. Granules are mostly missing but the content of silt varies and can reach up to $20.6 \%$. The deposits of these facies are thickly to very thickly-bedded. Remarkable is content of shell debris and clasts of shiny coal. Vertical shafts resembling Skolithos or Arenicolites trace fossils were rarely observed within SII. Deposits of FA 4 generally reveal a funnel shape of the wireline log (see Fig. 7) which is in good agreement with the results of facies analysis.

Samples from FA 4 provided micropalaeontological evidence represented by foraminifers and radiolarians. However, most tests of foraminifers are small, bad-preserved, corroded and damaged. Tests often contain pyrite. Assemblages of species are relatively diversified but they are also very poor in some intervals. Shallow water foraminifers (Ammonia, Asterigerinata, Elphidium) were observed but also deep water and euryoxybiont foraminifers (Heterolepa, Bulimina, Bolivina, Uvigerina, Pullenia, Nonion, Praeglobobulimina), and radiolarians were recognized. Such a situation probably documents mixing of shallow (warmer) water specimens and deeper (colder) water ones (Hladilová et al., 2014; Tomanová Petrová, 2016). Plankton, mainly globorotalias, predominates over benthos among foraminiers. Reworked Karpatian specimens of foraminifers (Uvigerina cf. graciliformis, Globigerina ottnangiensis, Cassigerinella sp., sphaeras) have been found. Due to the absence of Early Badenian index-fossils a strict stratigraphical position is uncertain but an Early Badenian age is supposed.

Interpretation: the relatively high degree of sorting and common clean texture suggest reworking by wave and/or tide action in a nearshore environment, which is consistent with the micropalaeontological data. A relatively proximal marine realm can be inferred from the coarser sediment calibre, content of mollusc shells and variety of sedimentary structures with dominance of low angle inclined planar parallel lamination. The occurrence of terrestrial organic matter debris suggests a fluvial depositional environment nearby (Dietrich et al., 2017). Sandstones of FA 4 are therefore interpreted as littoral/nearshore deposits formed in the sheltered bay. The occurrence of FA 2 immediately below FA 4 supports nearshore to shallow marine conditions and a possible support by a coarse-grained (shallow water?) delta. Generally, retrograding stacking patterns are inferred by FU arrangement.

Erosional unconformity/ravinement surface relatively flat produced by sea level rise and wave action is interpreted between FA 2 and FA 4. Such surfaces are typically underlain by continental deposits and covered by shoreface sediments (sensu Postma, 1995).

\section{FA 5 - OPEN MARINE DEPOSITS}

The facies association forms the uppermost part of the Neogene succession (ranging from 12.8 to $63.4 \mathrm{~m}$ - i.e. thickness of $50.6 \mathrm{~m}$ ) and volumetrically represents $21.1 \%$ thereof (Fig. 6B).

FA 5 is composed of four lithofacies ( $\mathrm{Mm}, \mathrm{Ml}, \mathrm{Ms}$ and $\mathrm{Hf}$ ) which are mostly very thickly bedded. Both the volumetric proportion of lithofacies and their distribution within the succession of FA 5 vary. Laminated mudstones (facies MI) form $9.1 \%$ of FA 5 and were recognized in its lowermost part. The most common (21.8\%) massive mudstones (lithofacies $\mathrm{Mm}$ ) and massive to faintly laminated mudstone with sandy laminae (lithofacies Ms see Fig. 5E forming 5\%) built the middle part of FA 5 . The topmost part of FA 5 is built of rhythmites of facies $\mathrm{Hf}$ (Fig. 5F) (form- 
ing $14.2 \%$ of the succession). Deposits of FA 5 occur above FA 4 and are erosively cut by Quaternary fluvial deposits.

Mudstones are calcareous and rich in marine fossils, especially foraminifera with strongly prevailing plankton specimens, mostly globorotalias. Tests are well-preserved. The occurrence of Orbulina suturalis, Praeorbulina glomerosa circularis, Uvigerina macrocarinata and Martinottiella karreri indicates Middle Miocene, M5b Zone of Berggren et al. (1995) that is correlated with Early Badenian in the Central Paratethys regional stages. From the palaeoecological point of view, microfauna documents temperate deeper water (shelf-bathyal), fluctuation of oxygen in water, normal salinity. Very small tests occur in some layers, especially in the upper part of the profile (15.9-16.0 m). A typical Early Badenian foraminiferal assemblage with spines of echinoids and fish fauna (fish teeth and bones) indicating normal marine conditions was described in lower part of this interval (61.8-62.0 m). Some reworked Karpatian fossils (foraminifers, sphaeras) were also found.

Interpretation: deposits of FA 5 are Early Badenian in age and are mostly interpreted as suspension fallout deposits in an open marine environment (neritic zone). However, laminated mudstones and rhythmites point to episodic sediment delivery into the relative quiet pelagic conditions. This transport might be connected with turbidity currents connected with river-derived hypopycnal suspension plumes (Nemec, 1995).

\section{PROVENANCE ANALYSIS}

Provenance analysis is based on the pebble petrography and analysis of heavy minerals.

PETROGRAPHY AND SIZE OF PEBBLES AND COBBLES, SHAPE AND ROUNDNESS OF PEBBLES

The gravels can be classified as polymict with a strong dominance of pebbles of sedimentary rocks. Grey silty shales dominate in the pebble spectra $(31.6-54.8 \%)$ followed by grey greywackes (23.6-33.6\%). The cobbles or boulders of shales and greywackes also typically form the largest found extraclast (max. $80 \mathrm{~cm}$ ), but the exact size is difficult to measure due to the limited core extent (Fig. 4E). Shale pebbles are mostly discoidal (34.6-39.0\%) or bladed (34.0-37.2\%), less common are prolate (19.2-20.2\%) and even less spherical (8.0-12.8\%). They are mostly subangular (43.2-56.4\%) or angular (28.2-51.0\%). Subrounded shale pebbles are less common $(4.2-14.1 \%)$ and rounded ones are rare (1.0-1.9\%). Similarly wacke pebbles are mostly bladed (44.6-48.2\%) or discoidal (25.9-26.8\%). The spherical shape is minor (18.5-21.4\%) similarly to the prolate one $(7.1-7.4 \%)$. Greywacke pebbles are mostly subangular (46.3-46.4\%) or angular (33.9-46.3\%), whereas subrounded pebbles were less common (7.4-19.6\%). Light beige and grey limestone pebbles can represent 1.3 to $10.4 \%$ of the pebble spectra. Carbonate pebbles are discoidal (8.3-49.0\%), spherical (1.0-41.7\%), bladed (1.0-33.3\%) or prolate $(16.7-49.0 \%)$, subangular $(33.3-100.0 \%)$ or subrounded $(0.0-41.7 \%)$ or even angular $(0.0-25 \%)$. Sandstone pebbles form about $2 \%$ of the pebble spectra. Fine or middle grained, laminated, calcareous and non-calcareous, glauconitic sandstone varieties have all been encountered. Limestone and sandstone pebbles are max. $2 \mathrm{~cm}$ in diameter.

Quartz pebbles are quite common and form $5.4-30.0 \%$ of the pebble spectra. Whitish and milky quartz are the main varieties, with greyish and pinkish types subordinating. Pebbles are mostly spherical $(61.1-66.7 \%)$, less common are discoidal $(14.3-33.3 \%)$, bladed $(0.0-23.2 \%)$ or rod shaped $(0.0-3.6 \%)$ with a maximum diameter of about $2 \mathrm{~cm}$. They are commonly subangular (28.6-48.1\%) or subrounded (28.6-38.9\%) or even angular (13.0-42.9\%).

Crystalline rocks in general form only a very minor portion of the pebble suite and such pebbles are max. $1.5 \mathrm{~cm}$ in size. Metamorphic rocks are mostly represented by gneisses (up to $1 \%)$, quartzites $(0.8-3.6 \%)$ or mica schists (2.0-2.5). Pebbles of mica shists and gneisses are subangular, subrounded and rounded. Pebbles of quartzites are mostly angular to subangular. Magmatic rocks are represented by various types of granites, which can reach up to $2.5 \mathrm{~cm}$ in size and represent $1.7-3.2 \%$ of the pebble spectra. Granite pebbles are mostly subangular to subrounded, angular ones are less common. Significant variation in the roundness of pebbles was recognied in individual samples in the succession.

\section{PETROGRAPHY OF SANDSTONES AND CONGLOMERATES}

The petrographic composition of sandstones, conglomerates and breccias is similar through the FA 1, FA 2 and FA 3 succession. Whereas fine to medium-grained sandstones are well-sorted, coarse-grained sandstones and fine-grained conglomerates are sorted poorly. Smaller grains $(0.063-0.25 \mathrm{~mm})$ are often angular and sub-angular, whereas larger ones $(0.25-2.0 \mathrm{~mm})$ and small granules and pebbles are mostly rounded. Fragments of rocks (mostly Culmian siltstones and claystones) represent the dominant clastic component (usually about $70 \%$ ) of clastic component. Clasts of granitoids, phyllites, mica schists, gneisses, quartzites and carbonates (microsparitic and micritic limestones - partially dolomitized, limestones with ooides) form the remaining part of the rock fragment spectra. Grains of monocrystalline and polycrystalline quartz (angular to sub-rounded), K-feldspares, plagioclase, muscovite, biotite, chlorite and accesoric garnet, tourmaline and glauconite are less common. The particles of organic matter (plant remnants) have been also recognized. Porous to basal carbonate cement with remnants of clay minerals commonly corrodes clastic grains.

\section{HEAVY MINERAL ASSEMBLAGES AND COMPOSITION OF DETRITAL GARNET}

Translucent heavy mineral assemblages (THMA) were used as sensitive indicators of the provenance of psammitic detritus, intensity of weathering, length of transport and conditions of diagenesis. ZTR maturity index (modal \% sum of zircone + tourmaline + rutile) is generally used as reliable indicator of mineralogical maturity (Hubert, 1962). Two samples were taken also from the basement rock. The first one comes from fine Carboniferous greywacke (302 $\mathrm{m})$, the other one from breccia of greywacke $(304.5 \mathrm{~m})$ clasts with sandy matrix. Seven samples originated from FA 2 and FA 3 deposits and two samples from FA 4. The results are presented in Table 2.

Samples from FA 2, 3 and 4 were relatively homogeneous in THMA composition. The contents of dominant garnet vary between 79.3 and $96.4 \%$. The ZTR varies between 1.4 and $2.8 \%$. There is no apparent trend in composition related to the position of sample.

Garnet composition was analysed in two samples (FA 4 $63.6 \mathrm{~m}$ and FA 3-226.6 m). Almandine garnets dominate (see Fig. 8A, B). Three groups of garnets can be distinguished. The most common group $(60.9 \%)$ is represented by grossularalmandine garnets with subdued pyrope and spessartine component and a composition in the range $\mathrm{Alm}_{51-82} \mathrm{GrS}_{9-28} \mathrm{Prp}_{3-21} \mathrm{Sps}_{0-20} \mathrm{And}_{0-2 .}$. Pyrope-almandines repre- 
Translucent heavy mineral assemblages in studied samples from boreholes 2212_B Odry and 2212_W Odry

\begin{tabular}{|c|c|c|c|c|c|c|c|c|c|c|c|c|c|c|}
\hline Depth [m] & $63.6-63.8$ & $68.8-68.9$ & 82.5 & 146 & 162 & 225.5 & 226.6 & 250 & 258.8 & $274.0-274.1$ & $285.0-285.1$ & 287 & 302 & 304.5 \\
\hline Facies & FA 4 & FA 4 & $\begin{array}{c}\text { Grey } \\
\text { wacke } \\
\text { clast }\end{array}$ & FA 2 & FA 2 & FA 3 & FA 3 & FA 2 & FA 2 & FA 2 & FA 2 & FA 2 & $\begin{array}{l}\text { Bedrock, } \\
\text { greywacke }\end{array}$ & $\begin{array}{c}\text { Sandy } \\
\text { matrix } \\
\text { of } \\
\text { brec- } \\
\text { cia }\end{array}$ \\
\hline Garnet & 89.0 & 95.9 & 23.3 & 92.6 & 92.1 & 96.1 & 94.8 & 94.1 & 79.3 & 95.3 & 92.7 & 93.2 & 21.0 & 93.3 \\
\hline Zircone & 0.5 & 0.3 & 30.0 & 0 & 0.3 & 0 & 0.7 & 0 & 0.7 & 0 & 0 & 0 & 0 & 0 \\
\hline Apatite & 4.7 & 0.3 & 40.0 & 0.7 & 2.2 & 0.8 & 1.0 & 2.1 & 14.5 & 0.3 & 0.9 & 1.9 & 14.5 & 1.8 \\
\hline Rutile & 0.7 & 0.8 & 3.3 & 0.6 & 0 & 0 & 0.2 & 0 & 1.0 & 0 & 0.2 & 0.2 & 0 & 0.5 \\
\hline Tourmaline & 1.6 & 0.3 & 3.3 & 0.4 & 1.3 & 0.2 & 0.7 & 0.4 & 0.3 & 0.3 & 0.6 & 1.7 & 0 & 0.2 \\
\hline Epidote & 0.2 & 1.1 & 0 & 0.9 & 1.3 & 0.3 & 0.2 & 0.8 & 1.9 & 0.3 & 0.9 & 1.9 & 1.6 & 0.5 \\
\hline Staurolite & 1.6 & 0.5 & 0 & 3.5 & 0.6 & 1.9 & 0.7 & 1.0 & 1.2 & 1.4 & 2.6 & 0.4 & 0 & 1.6 \\
\hline Amphibole & 0 & 0 & 0 & 0.2 & 0.6 & 0 & 0.2 & 0 & 0 & 0 & 0 & 0 & 0 & 0 \\
\hline Titanite & 0 & 0 & 0 & 0 & 0 & 0 & 0 & 0 & 0 & 0 & 0 & 0 & 0 & 0 \\
\hline Kyanite & 0.9 & 0.5 & 0 & 0.4 & 1.0 & 0.5 & 0.2 & 1.0 & 0.7 & 0.6 & 0.9 & 0.6 & 0 & 1.8 \\
\hline Alterite & 0 & 0 & 0 & 0 & 0 & 0 & 0.2 & 0 & 0 & 0.6 & 0.2 & 0 & 0 & 0 \\
\hline Chromspinel & 0 & 0 & 0 & 0.7 & 0 & 0 & 0 & 0 & 0.2 & 0 & 0 & 0 & 0 & 0 \\
\hline Sillimanite & 0.2 & 0 & 0 & 0 & 0.6 & 0 & 0.3 & 0.4 & 0 & 0.6 & 0.7 & 0.2 & 0 & 0 \\
\hline Glaucophane & 0.2 & 0 & 0 & 0 & 0 & 0.2 & 0 & 0 & 0 & 0 & 0.2 & 0 & 0 & 0 \\
\hline Monazite & 0.2 & 0 & 0 & 0 & 0 & 0 & 0 & 0 & 0 & 0 & 0 & 0 & 0 & 0 \\
\hline Pyroxene & 0 & 0.3 & 0 & 0 & 0 & 0 & 0.3 & 0 & 0.3 & 0.3 & 0 & 0 & 0 & 0 \\
\hline Brookite & 0 & 0 & 0 & 0 & 0 & 0 & 0 & 0 & 0 & 0 & 0 & 0 & 17.7 & 0 \\
\hline Sagenite & 0 & 0 & 0 & 0 & 0 & 0.2 & 0.3 & 0 & 0 & 0.2 & 0.2 & 0 & 45.2 & 0.4 \\
\hline ZTR index & 2.8 & 1.4 & 36.6 & 1.0 & 1.6 & 0.2 & 1.6 & 0.4 & 2.0 & 0.3 & 0.8 & 1.9 & 0 & 0.7 \\
\hline $\begin{array}{l}\text { Number } \\
\text { of counted } \\
\text { grains }\end{array}$ & 427 & 365 & 30 & 540 & 315 & 640 & 401 & 478 & 681 & 640 & 464 & 483 & 62 & 568 \\
\hline
\end{tabular}

sent the second group (32.6\%) with the typical composition in the range $\mathrm{Alm}_{60-83} \mathrm{Prp}_{9-26} \mathrm{Grs}_{1-14} \mathrm{Sps}_{0-12} \mathrm{And}_{0-2}$. The last group $(6.5 \%)$ form spessartine-almandines with compositions of Alm $_{61-68} \mathrm{Sps}_{14-25} \operatorname{Prp}_{5-11} \mathrm{Grs}_{8-10} \mathrm{And}_{0-2}$. The composed diagram (Fig. 8) allows a comparison with garnets from possible source areas.

\section{INTERPRETATION OF THE PROVENANCE DATA}

Polymict gravels with dominance of sedimentary rocks and minor content of magmatic and metamorphic rocks point to a source from older sedimentary units with a complex history. The strong prevalence of commonly angular to subangular shales and greywackes, with a bladed shape and constituting the largest clasts, all point to a significant role of source from the Culmian rocks. Pebbles strongly follow the original shape connected to bedding or cleavage and the poor rounding support the local source. The source of crystalline rocks and quartz could be from the Culmian conglomerates. The anhedral quartz grains suggest a primary origin from metaquartzites. Angular quartz grains with shard shape and felsitic grains can be attributed to a source from acid volcanic rocks. The presence of mica shows on mica schists or leucogranites in the primary source area.

The source from "Culmian facies" of the Moravian-Silesian Paleozoic is further supported by similar size, shape and roundness of the pebbles. However, significant variations in the pebble roundness and content of quartz signalise multiple sources and the role of redeposition. This assumption is further supported by the content of carbonates and sandstones (especially glauconitic ones), which are quite rare in the bedrock in the close vicinity of this locality.

The recognized translucent heavy mineral assemblages (THMA) and detrital garnet composition provided important provenance data. Several geological units (rich in detrital garnets) had to be taken into account. THMA from local basement rocks (eastern and western vicinity of the borehole Odry) reveals a typical assemblage of the greywackes of the Hradec-Kyjovice Fm. of the Moravian-Silesian Paleozoic (Hartley and Otava, 2001). The assemblage from greywacke boulder (Table 2, column 3) within FA 2 deposits and high ZTR index support local source from the Kyjovice Member of the Hradec-Kyjovice $\mathrm{Fm}$. of the boulder. The relative higher share of apatite in several samples of fine-grained sands (Table 2, columns 1 and 9) supports the provenance from distal parts of the Culmian basin.

However, there are significant differences between THMA of local greywackes and of the studied Miocene deposits. The main difference is minor but stable share of minerals like staurolite, kyanite, sillimanite and some others, which are totally absent within Culmian beds (see Table 2). These minerals reflect probably subsidiary redeposition from eroded remnants of the Cretaceous beds which formerly covered the Bohemian Massif and were documented in the nearby area of Hranice Karst (Otava et al., 2016). These minerals are also quite common in the Karpatian sands southerly and southwesterly from the studied area (Francírek et al., 2014; Bubík et al., 2018). Moreover, the compositional range of detrital garnets of the studied Miocene deposits (see Fig. 8) is wider than the assemblage of greywackes of the Hradec-Kyjovice Fm. Local bedrock belongs to the 

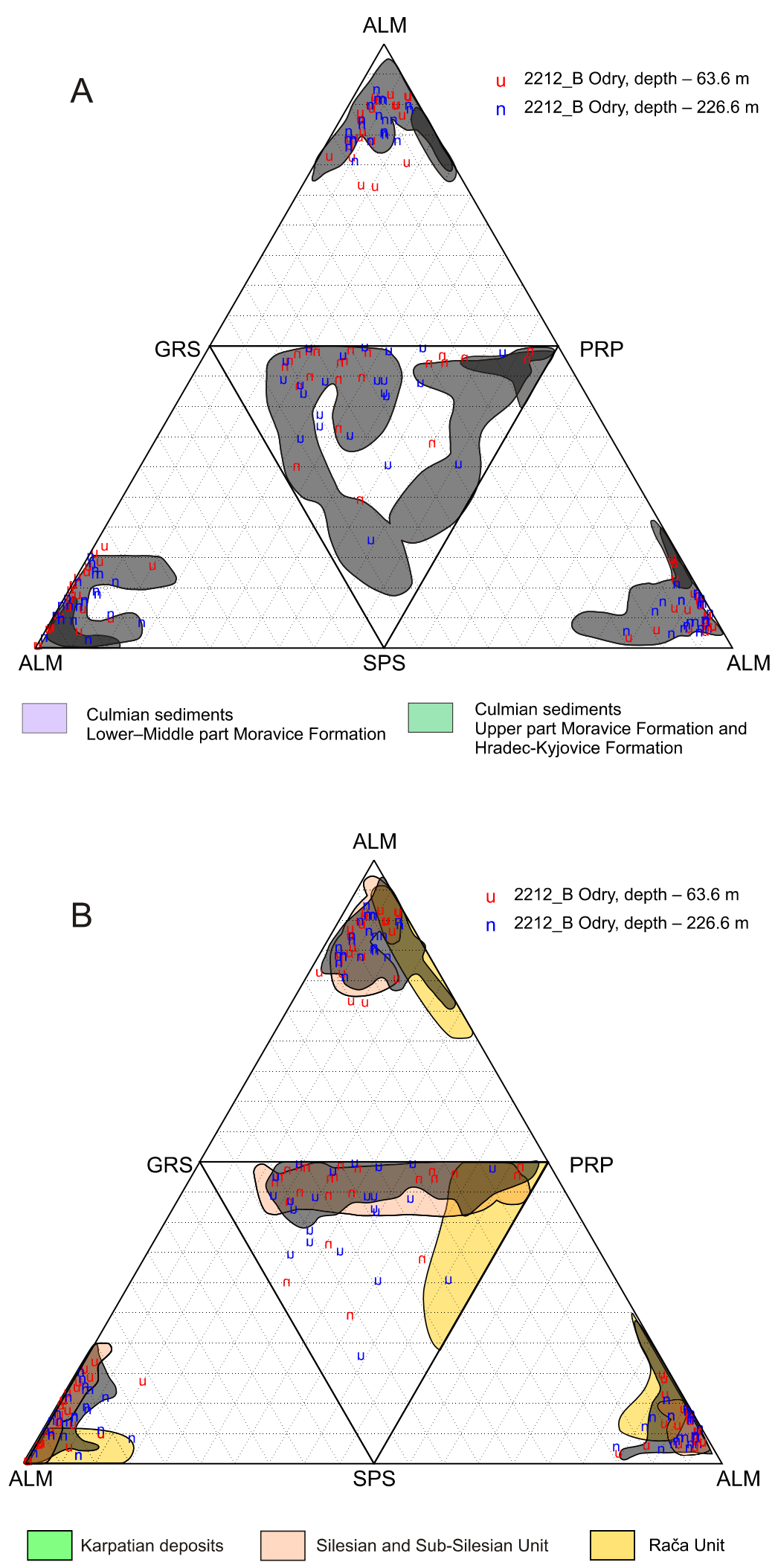

Fig. 8. Ternary diagrams of the chemistry of detrital garnets

A - ternary diagram of the chemistry of detrital garnets in comparison with possible source areas from the Culmian bedrock; data from source rocks according to Otava (1998) and Čopjaková et al. (2002); B - ternary diagram of the chemistry of the detrital garnets and comparison with garnets from the Karpatian deposits of the Carpathian Foredeep, Silesian + Sub-Silesian Units and Rača Unit of the Western Carpathian Flysch Zone (source data - Francírek et al. (2014), Francírek and Nehyba (2016); (ALM almandine, GRS - grossular, PRP - pyrope, SPS - spessartine) oligomictic zone (Hartley and Otava, 2001) with pyrope-almandines, while other garnet groups are highly reduced.

The range of composition of detrital garnets from older Culmian greywackes (exposed westwards from the area under study) reveal are rich in garnets is quite similar to that of the studied Miocene sands. However, ultrastable and mesostable minerals (zircon, epidote, titanite) typomorphic for "older" greywackes (Otava, 1998; Čopjaková et al., 2002; Franců and Otava, 2014) are absent or very highly reduced in the studied Miocene sands. Thus older greywackes as unique and dominant source of detritus is not probable.

Sandstones of the flysch units of the Western Carpathians are often rich in garnets with staurolite as a common minor component. The range of detrital garnet composition of sandstones of the Silesian and Subsilesian Units is mostly identical with detrital garnets of Miocene deposits studied (see Fig. 8). Moreover, Karpatian deposits of the Carpathian Foredeep (Francírek et al., 2014; Francírek and Nehyba, 2016) are also garnet rich and display a very similar polymictic range of detrital garnets as studied deposits.

To conclude and sum up, the Miocene sedimentary pile of the Odra palaeovalley had a multiple source. Provenance from both the Lower Carboniferous clastic deposits and an older sedimentary infill of the Carpathian Foredeep (most probably Karpatian in age) was important.

\section{SEISMIC INVESTIGATION}

The results of the new reflection seismic survey are presented in Figure 9. The data is shown in colour palettes used for seismic amplitude display (minimum is blue, maximum is red). Seismic data was interpreted along with other methods - gravity, electrical profiling and sounding (unpublished reports of project "Review of groundwater resources in the Czech Republic"). The seismic profile P9-3 crosses the Odra palaeovalley in its southern part (see Fig. 1A). The Quaternary sediments and weathering zone is manifested as homogeneous, non-reflective zone about 30-40 m thick. At deeper level, the seismic data is characterized by presence of relatively horizontal sequence of high-amplitude low frequency reflectors of Neogene sediments. The laminated character indicates probably changes in the lithology (sand and clay layers have been described in borehole 2212_B) but it can contribute also the multiple reflection from groundwater level (the multiples removal was not implemented). The basement is manifested by the different character of the seismic signal (high to medium-amplitude 


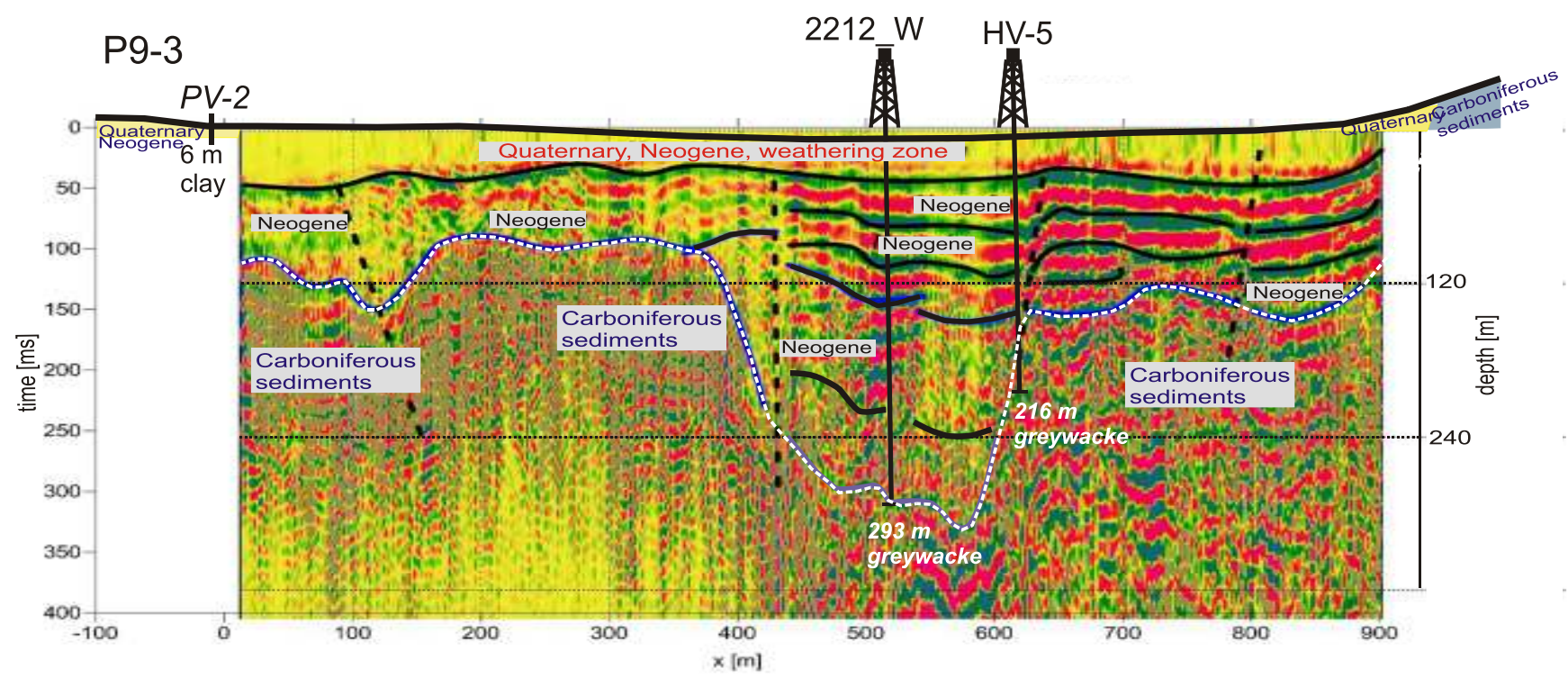

Fig. 9. Seismic cross-section of profile P9-3

Interpretation of the shallow reflection seismic survey: high and large-amplitude subhorizontal reflections indicate thin Neogene sediment layers (sand and interbedded clay), distinctive high-frequency signal represents a Paleozoic rocks; seismic image shows the relief of basement across of the Odra palaeovalley

and high frequency). On the profile between 400-600 $m$ the discontinuation of reflections in sedimentary layers indicate the faults (verify on surface also by electric profiling), which limited deep scarp with a width of about $200 \mathrm{~m}$. The short-period and relatively chaotic seismic signal at a depth of 120 to $300 \mathrm{~m}$ can be an evidence of clastic sediments (sand, gravel or breccia).

The previous geophysical survey (results of deep reflection seismic and gravity is described in unpublished technical reports of Geofyzika, state-owned enterprise) was focused to find deep tectonic structures in the Paleozoic basement and thickness of Miocene sediments in the Central Depression of the MCF (Tomek et al., 1987). Four reflection seismic profiles (P1P4) oriented in the NW-SE and WSW-ENE direction were measured in the study area (see Fig. 1A). Seismic measurements were realized using vibroseis with 12-fold overlapping and data were processing to time-cross-section. Detailed gravity measurement in this area was used for gravity modelling on seismic profiles P2 and P3. New seismic profile P9-4 was situated similarly as the profile P4 perpendicular to the structure of the Moravian Gate and parallel with the Odra palaeovalley (see Fig. 1A and 10). The boundary of individual strata on the P4 profile was correlated with the borehole BL-1. Previous seismic measurements with distance between geophones $25 \mathrm{~m}$ were realized for depth range to several kilometres, whereas new measurements with distance of geophones $4 \mathrm{~m}$ were focused on first hundred metres. The relationship of both allow to interpret shallow and depth reflectors together. The top of Paleozoic basement is characterized by reflection with high amplitude and good continuity. The basement is smoothly dipping to the depression of the Moravian Gate. Two main seismic facies above it can be observed in profile P4 (correlation with BL-1):

- Neogene sediments characterized by reflection with high amplitude and low frequency,

- clastic sediments without reflections.

In the Neogene sediments the sequence of steeply dipping reflectors $(A)$ to the Moravian Gate from distance of the seismic profile P9-4 1400 to 1500 m can represent the sedimentary succession at the mouth of the Odra palaeovalley.

Interpretation: interbedding of the Neogene sediments (clay and sand) in the seismic profile P9-3 are characterized by reflections with the high amplitude and good continuity. The thickness of these sediments in the eastern part is about $80 \mathrm{~m}$, in the western part about $40 \mathrm{~m}$. The section of the profile between 400-600 m has little reflected energy at a depth of 120 to $300 \mathrm{~m}$. This can indicate sediments with a massive, non-stratified character, for example sand, gravel, conglomerate or breccia. The top of Carboniferous is indicated by a changing of wave frequency and low amplitudes. The deep scarp of the basement (Fig. 9) limited by faults probably represents the outflow channel of the Odra palaeoriver mouth. This palaeovalley is relatively deep (about $300 \mathrm{~m}$ ).

New shallow seismic measurements and the previous deep seismic survey (i.e. profiles P9-4 and P-4) have for the deeper parts of the succession very similar results. The top of basement represents distinctive interface. The basement slightly dips towards SE, to the depression of Moravian Gate. In the seismic profile P9-4 the subhorizontal reflections with good continuity (especially in the deeper southeastern part) are visible above it. This probably indicates alternating layers of sand and clay. The change of P-wave velocity at interfaces between clayey and sandy sediments has been documented by VSP (Vertical Seismic Profiles) in borehole BL-1 (a distinctive velocity interface was documented between the 5 beds of pelitic and the clastic sediments in Filková, 1984). The sequence of low-angle NE-dipping reflectors (A) concentrated on the profile P9-4 can manifest the foreset of the coarse-grained Gilbert-type delta.

\section{GAMMA-RAY SPECTRAL ANALYSIS}

The gamma-ray analysis (GRS) is used for identification of lithology, grain size, sorting, processes in the source area and 


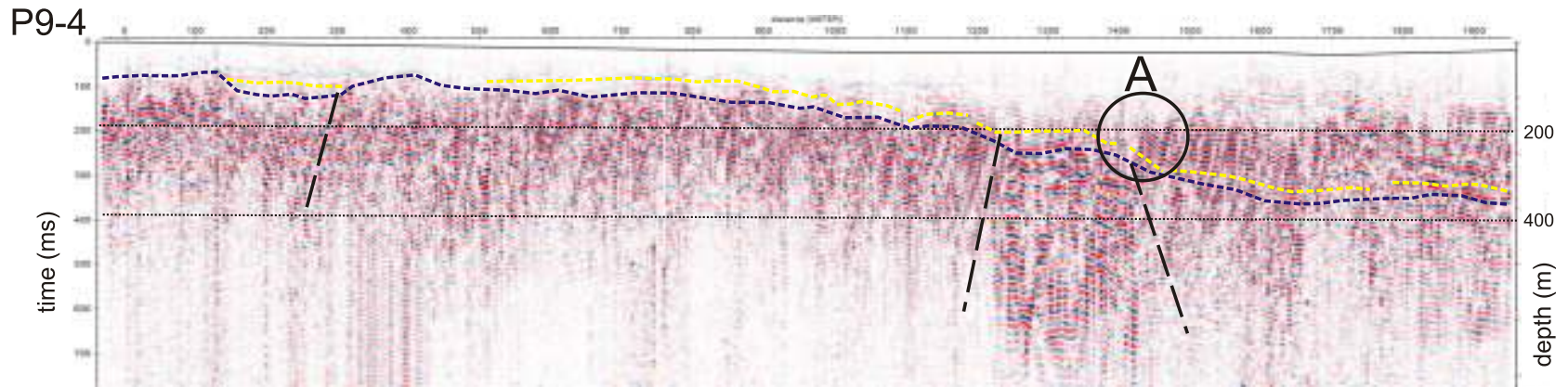

P4

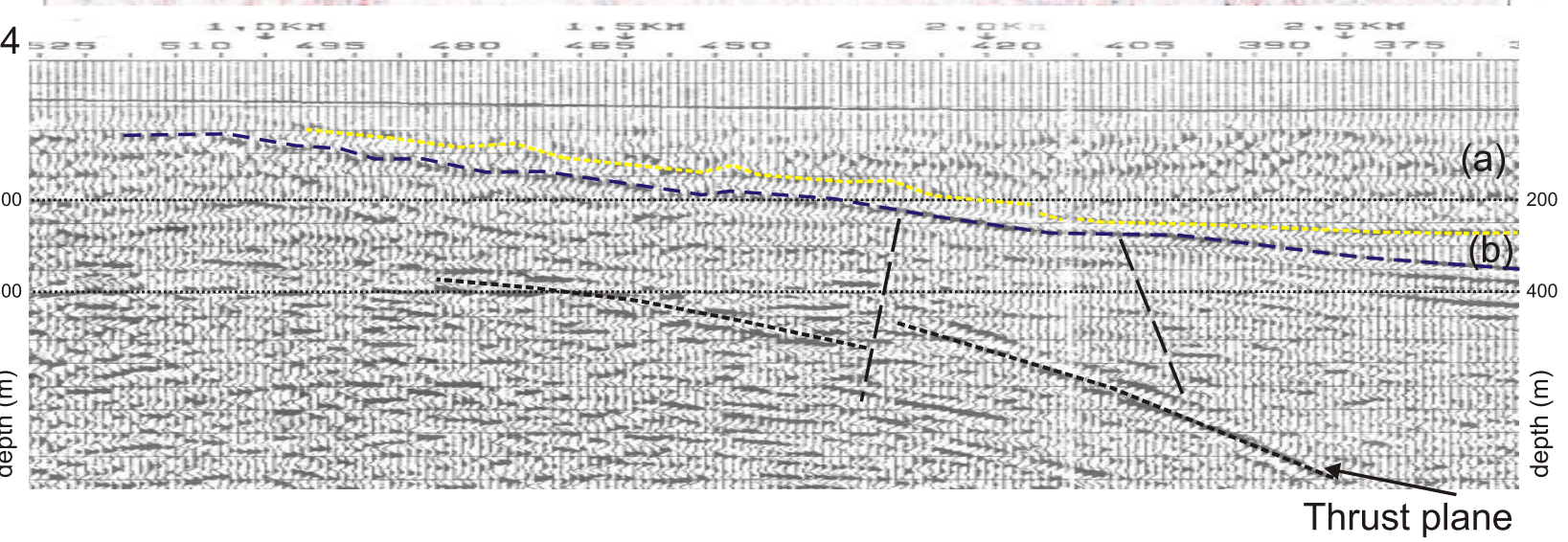

Fig. 10. Interpretation of two seismic cross-sections along Odra palaeovalley: shallow reflection survey P9-4 (up) and deep reflection survey $\mathrm{P} 4$ (down)

Top of clastic sediments (yellow) and basement presented by Culmian facies (blue); shallow survey indicates sequence of sloping sedimentary layers $(A)$ on the NW margin of the Carpathian Foredeep at the mouth of the Odra palaeovalley; the NW fault zone of the Carpathian Foredeep is characterized by high-amplitude reflections (up) and sloping reflections (down), which can correspond with deformation zone and thrust plane

its composition, identification of clay minerals, content of organic matter, basin-wide correlations, identification of the depositional environment, etc. (Ruffell and Worden, 2000; Akinlotan, 2017) especially in monotonous lithology. The results are presented in Table 3 and Figure 6B. The deposits of FA 2 reveal relatively stable gamma ray spectra. The concentrations of $\mathrm{K}, \mathrm{U}$ and Th are mostly moderate whereas high concentrations are less common (classification according to Hasselbo, 1996). The values of both the $\mathrm{Th} / \mathrm{K}$ and $\mathrm{Th} / \mathrm{U}$ ratio are all relatively low. The Th and $\mathrm{K}$ concentrations show a relatively high positive correlation (linear regression coefficient $R=0.62$ ). The correlation of concentrations of $\mathrm{K}$ and $\mathrm{U}$ is significantly lower $(R=0.20)$ and the correlation between the concentrations of Th and $U$ are close to zero $(R=0.05)$. The value of total radioactivity $S G R$ shows very high correlation to values of Th $(R=0.85), U(R=$ $0.85)$ and less of $U(R=0.44)$.

The concentration of $\mathrm{K}$ can be classified mostly as low and the concentrations of $U$ can be evaluated as low to moderate within the overlying FA 4 and FA 5 deposits. The concentrations of Th can be evaluated as moderate and high for both FA 4 and FA 5. The value of the Th/K ratio is mostly low. Rider (1996) considers such Th/K ratio 4 to 6 as "normal". The value of the $\mathrm{Th} / \mathrm{U}$ ratio ranges from low to high values for FA 4, but for FA 5 is relatively high, although according to Rider (1996) such a $\mathrm{Th} / \mathrm{U}$ ratio is normal. The correlation between the concentrations of $\mathrm{K}$ and $\mathrm{U}$ is relative moderate $(R=0.47$ for $F A 4$ and $R=$ 0.51 for FA 5). The correlation between $K$ and Th is relatively moderate $(R=0.51)$ for $F A 4$ deposits but relatively high $(R=$
$0.65)$ for $F A$ 5. The correlation between $U$ and Th is relatively high $(R=0.61)$ for FA 4 but low $(R=0.3)$ for FA 5. The value of total radioactivity SGR shows very high correlation to values of Th $(R=0.87), U(R=0.84)$ and also $K(R=0.77)$ in the case of FA 4. The value of total radioactivity SGR shows a very high correlation to values of $K(R=0.89)$, Th $(R=0.80)$ and also $U$ ( $R$ $=0.74)$ for FA 5. A zero to very low positive correlation was recognized between $\mathrm{K}(R=0.07)$, Th $(R=0.11), U(R=0.02)$ and clay content for deposits of FA 5 . Similarly, zero to very low positive correlations were recognized between $K(R=0.06)$, Th ( $R$ $=-0.03), U(R=0.12)$ and silt content.

Interpretation: the significant correlations between "total radioactivity" SGR and concentrations of $\mathrm{K}$, Th and U together with correlations between individual elements (especially Th versus $\mathrm{K}$ ) point to a common source of signal. Th and $\mathrm{K}$ are commonly found to be linearly related in siliciclastic mudstones. Variations in the value of correlations within individual FA point to the role of lithology/grain size. The similarity between the concentrations of $\mathrm{U}, \mathrm{K}$ and $\mathrm{Th}$ in lithologically different $\mathrm{FA} 2$ and FA 5 can be connected with a high content of pebbles of shales and wackes in the FA 2 (Adams and Weaver, 1958). A rapid increase especially of Th content (significantly lower increase of $K$ and $U$ content) along FA 4 and $F 5$ boundary (see Fig. 6B) is related to a greater volume of clay minerals in the FA 5 deposits compared to FA 4. A systematic upward increase of the gamma-ray signal (observing FA 4 and FA 5 successions) is also obvious from the wire-line logs (see Fig. 7). The lowest content of $U$ in FA 5 reveals that organic matter is present here 
Results of gamma-ray spectral analysis

\begin{tabular}{|c|c|c|c|c|c|c|c|c|c|c|c|c|}
\hline \multirow{2}{*}{$\begin{array}{c}\text { Facies } \\
\text { association }\end{array}$} & \multicolumn{2}{|c|}{$\mathrm{K}[\%]$} & \multicolumn{2}{c|}{$\mathrm{U}[\mathrm{ppm}]$} & \multicolumn{2}{c|}{ Th [ppm] } & \multicolumn{2}{c|}{ SGR [API] } & \multicolumn{2}{c|}{ Th/K } & \multicolumn{2}{c|}{ Th/U } \\
\cline { 2 - 13 } & $\begin{array}{c}\text { AVG } \\
(\text { Min-Max) }\end{array}$ & SD & $\begin{array}{c}\text { AVG } \\
(\text { Min-Max) }\end{array}$ & SD & $\begin{array}{c}\text { AVG } \\
\text { (Min-Max) }\end{array}$ & SD & $\begin{array}{c}\text { AVG } \\
(\text { Min-Max })\end{array}$ & SD & $\begin{array}{c}\text { AVG } \\
\text { (Min-Max) }\end{array}$ & SD & $\begin{array}{c}\text { AVG } \\
\text { (Min-Max) }\end{array}$ & SD \\
\hline FA 2 & $\begin{array}{c}1.8 \\
(1.5-2.4)\end{array}$ & 0.2 & $\begin{array}{c}3.3 \\
(3.0-4.1)\end{array}$ & 0.3 & $\begin{array}{c}6.4 \\
(4.9-9.5)\end{array}$ & 1.1 & $\begin{array}{c}81.8 \\
(70.0-105.6)\end{array}$ & 7.8 & $\begin{array}{c}3.5 \\
(2.3-4.1)\end{array}$ & 0.5 & $\begin{array}{c}1.9 \\
(1.3-2.6)\end{array}$ & 0.4 \\
\hline FA 4 & $\begin{array}{c}1.7 \\
(1.2-2.0)\end{array}$ & 0.3 & $\begin{array}{c}2.8 \\
(2.2-4.4)\end{array}$ & 0.7 & $\begin{array}{c}6.3 \\
(4.7-8.8)\end{array}$ & 1.5 & $\begin{array}{c}75.1 \\
(5.4-100.0)\end{array}$ & 13.6 & $\begin{array}{c}3.8 \\
(2.7-4.7)\end{array}$ & 0.8 & $\begin{array}{c}2.3 \\
(1.8-3.3)\end{array}$ & 0.5 \\
\hline FA 5 & $\begin{array}{c}2.0 \\
(1.5-2.8)\end{array}$ & 0.3 & $\begin{array}{c}2.4 \\
(1.6-4.2)\end{array}$ & 0.5 & $\begin{array}{c}8.7 \\
(6.7-11.8)\end{array}$ & 1.1 & $\begin{array}{c}85.9 \\
(67.4-118.8)\end{array}$ & 10.2 & $\begin{array}{c}4.4 \\
(3.6-5.5)\end{array}$ & 0.5 & $(2.17-6.80)$ & 0.8 \\
\hline
\end{tabular}

AVG - average concentration, SD - standard deviation, SGR - total radioactivity

in a minor amount (open marine deposits). Generally low facies control on Th-U-K characteristics (cf. Myers and Bristow, 1989) can be documented and the same source of the material for deposits of all FA can be supposed.

Any systematic upward trend in distribution of Th, $\mathrm{K}$ or $\mathrm{U}$ was recognized within the profile of "uniform" mudstones of FA 5. However, the lower part of FA 5 (facies $\mathrm{Ml}$ - datum 54-63 m) reveals the highest concentrations of $\mathrm{K}, \mathrm{Th}, \mathrm{U}$ and the highest total counts, together with the lowest $T h / U$ values of the FA 5 succession. This observation is explained by transgressive conditions. The lower gamma-ray signal in the upper part of FA 5 succession is explained by a more reduced delivery of sediment into the basin (i.e. max. flooding to highstand condition).

The relatively low $\mathrm{Th} / \mathrm{K}$ ratios in FA 2 and FA 4 are generally the result of the relatively low heavy mineral concentrations and low mineral and chemical maturity of the deposits (Hampson et al., 2005) and are also connected with the source rocks, poor weathering and rapid deposition (Mange-Rajetzky, 1995; Morton and Berge, 1995; Morton and Hurst, 1995). The slightly higher $\mathrm{Th} / \mathrm{K}$ ratio for $\mathrm{FA} 4$ compared to $\mathrm{FA} 2$ reveals the higher chemical maturity of deposits of FA 4. Relative high stability of the $\mathrm{Th} / \mathrm{K}$ ratio implies relative stability of mineralogical composition within all studied FA.

The $\mathrm{Th} / \mathrm{K}$ ratio can be applied to the recognition of clay minerals and distinction of micas and K-feldspars within mudstones of FA 5 (Doveton and Merriam, 2004). The relatively low Th/K value (together with the relatively high Th content) reveal the humid condition of weathering which led to mobilisation and leaching $\mathrm{K}$ (and also $\mathrm{U}$ ), while concentrating $\mathrm{Th}$ in the hinterland soils. These detrital clays relatively depleted in $\mathrm{K}$ and $\mathrm{U}$ are trapped in the basin (Schnyder et al., 2006). The relative stability of the Th/K ratio implies that clay mineralogy (e.g., the kaolinite/illite ratio) did not change during FA 5 deposition, for example in response to the climate (Rider, 1996). The occurrence of clasts of coal in FA 2 and FA 3 is consistent with a relatively uniform, humid, subtropical climate throughout its deposition.

The $U$ versus Th plot (Fig. 11A) indicates that while the most of the FA 2 samples are located above the separation line, the FA 4 samples are distributed almost symmetrically along the line and all the FA 5 samples are below the line. The enrichment of $U$ is explained mostly by the higher content of organic matter (especially in FA 2), whereas the points below the lines (FA 5) correspond to very low organic matter and humid conditions (Myers and Wignall, 1987; Ruffell and Worden, 2000). The "normal" $\mathrm{Th} / \mathrm{U}$ ratio for FA 5 is in coincidence with its marine origin (Adams and Weaver, 1958; Myers and Wignall, 1987).

A cross plot of Th/K versus Th/U ratios is presented in Figure $11 \mathrm{~B}$ and indicates a distribution, which can be related to the recognized FA and grain size. The higher values of especially the $\mathrm{Th} / \mathrm{U}$ ratio and also $\mathrm{Th} / \mathrm{K}$ for samples from FA 5 are obvious. Mudstones of FA 5 are all clustered in mixed-layer clays. Some variations can be explained by different intensity of weathering in the source area (Ruffell and Worden, 2000; Schnyder et al., 2006).

\section{DISCUSSION - STRATIGRAPHIC ARCHITECTURE AND EVOLUTION OF THE PALAEOVALLEY DEPOSITION}

The stratigraphic arrangement of the generally fining-up and deepening-up sedimentary succession of the confined Odra palaeovalley provides a record of the interplay between the available accommodation space (A), and the sediment supply (S), expressed as the "A/S ratio" (Postma, 1984; Jervey, 1988; Muto and Steel, 1997; López and Blanco et al., 2000; Breda et al., 2009; Backert et al., 2010; Gobo et al., 2014). The location of the palaeovalley on the forebulge basinward flank suggests that the valley accommodation space was controlled by both tectonics and eustatic sea level changes (Gawthorpe and Collela, 1990; Catuneanu et al., 1998; Catuneanu and Sweet, 1999; Blum and Törnqvist, 2000; Bruhn and Steel, 2003; Leszczyński and Nemec, 2015). Accommodation in alluvial fan systems is moreover controlled by tectonic uplift of the source area, palaeotopography, geology of the drainage basin and climate (Shanley and McCabe, 1994; Gupta, 1999; Viseras et al., 2003; Andreucci et al., 2014). The role of these individual factors recorded in the sedimentary history of the studied palaeovalley varied similarly to the depositional environments. Four recognizable stages of valley evolution, connected with significant changes in A/S ratio, can be identified and graphically summarized in Figure 12.

Stage A: increased crustal loading by a thickened orogenic wedge propagating generally towards the NW results in a new flexure shape of the basin. As the thrust load increased, the mechanical strength of the basement was exceeded in front of the thrust wedge and fault activity increased along zones of basement weakness (see Waschbusch and Royden, 1992). Here, the bedrock-confined Odra palaeovalley developed within the forebulge zone perpendicular to the basin main along the NW-SE trending basement faults ("sudetic fault system"; Fig. $12 \mathrm{~A})$. The entrenchment of the Odra palaeovalley was accompanied by the formation of a steep base level profile and base level fall (negative accommodation) connected with an intense pre-mid Miocene erosion. The marginal fault (NE-SW trending) 

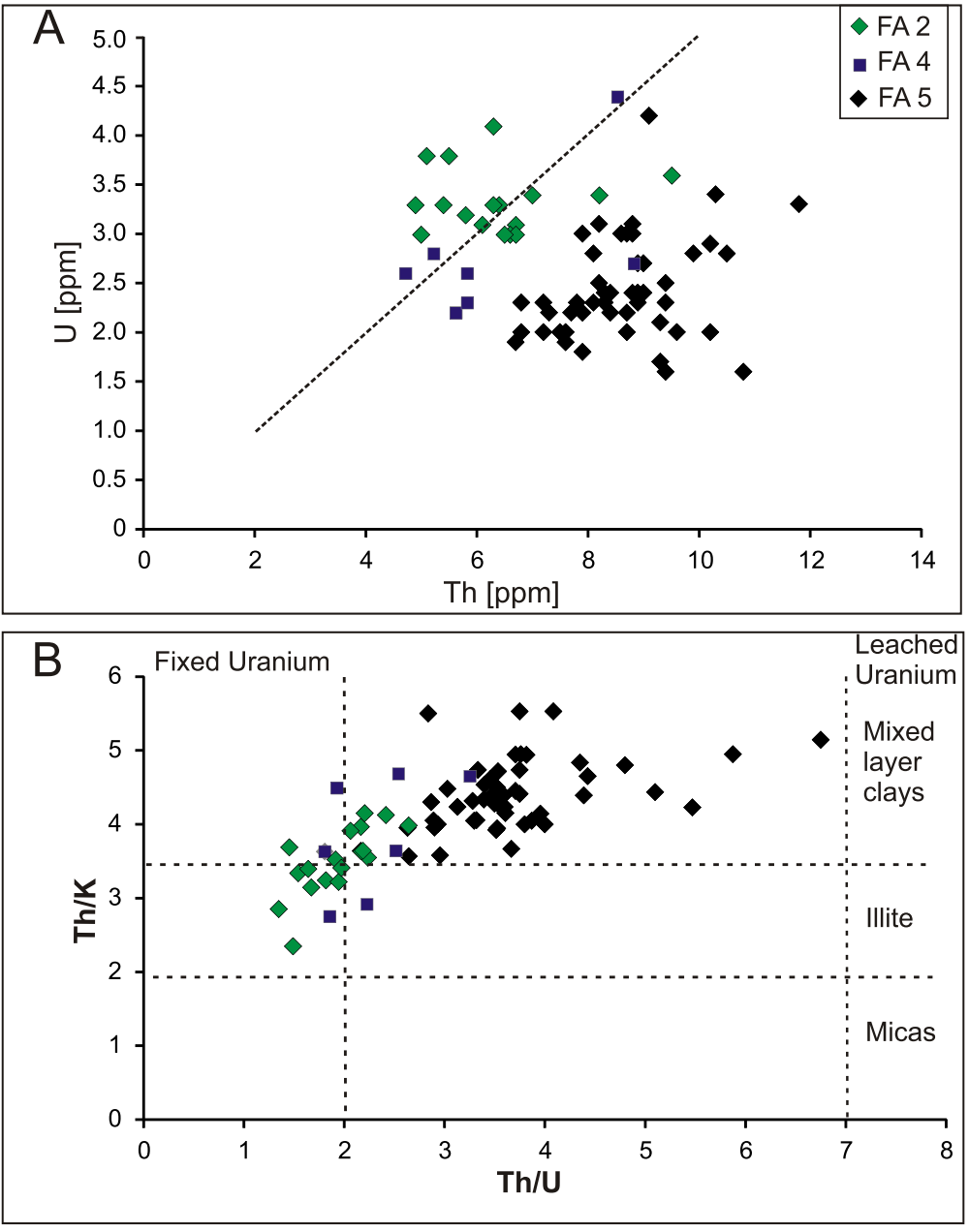

Fig. 11 Results of gamma-ray spectral analysis

A - crossplot of $U$ versus Th with a discrimination line Th/ $U=2$; B - crossplot of $\mathrm{Th} / \mathrm{K}$ versus $\mathrm{Th} / \mathrm{U}$ ratios showing the redox-condition of studied deposits

(FA 2, 4 and 5) as well as the types of clays

limiting the Central Depression towards the foreland had a similar origin (see Cogan et al., 1993). The erosional floor of the Odra palaeovalley, as a subaerial unconformity (see FA 1 deposits), is considered as a sequence boundary/basal unconformity of the valley succession.

Morphologically similar structures are known from the North Alpine Foreland Basin (Kempf and Pfiffner, 2004) or from the Polish part of the Carpathian Foredeep Basin (Oszczypko and Ślaczka, 1985; Krzywiec, 1997, 2001; Krysiak, 2000; Głuszyński and Aleksandrowski, 2016). The origin of the palaeovalleys in Poland is commonly explained by regional Late Cretaceous-Paleogene inversion of the Carpathian foreland and deep incision along the Tethyan shelf that followed this uplift and erosion (Karnkowski, 1989; Krzywiec, 1997, 2001; Oszczypko et al., 2006). This interpretation is supported by the comparison with tectonically controlled erosional Vranovice and Nesvačilka palaeovalleys known from subsurface of the southern segment of MCF and filled with thick Paleogene beds (Picha et al., 2006). However, Jarosiński et al. (2009) connected the incision of the Polish Carpathian Foreland with Late Oligocene to Early Miocene formation of the forebulge in front of the approaching Carpathian flysch fold-and-thrust wedge. Unlike the above mentioned palaeovalleys of the Polish Carpathian foreland, the Odra palaeovalley is significantly smaller (less laterally extended and shallower), it is formed on the cratonward/distal margin of the basin, and convincing geophysical indication of its continuation below foreedep zone of the MCF and below the nappes of the Outer Western Carpathians is missing. Very similar sedimentary succession and palaeotopography of the Odra palaeovalley can be traced with deposition in submerged overfilled alluvial valleys (rias) or fjords (Postma, 1984; Prior and Bornhold, 1990; Somoza and Rey, 1991; Breda et al., 2007, 2009).

The timing of the major Odra palaeovalley entrenchement is here preliminary put into Early Miocene. It is supposed that the incision shortly or directly preceded the deposition of the infill of the palaeovalleys. The entrenchement is possibly connected with the Early/Middle Miocene sea level fall (e.g., Hoheneger et al., 2014). However, a more complex evolution of this palaeovalley is probable, with alternation periods of erosion and deposition reflecting variations in the tectonic regime, subsidence and uplift events, sea level and climatic changes. The Paleogene incision of the Odra palaeovalley entrenchment could not be definitely ruled out.

The valley incision gives evidence of an erosional agent of sufficient capacity and points to sediment bypass into the inner/proximal parts of the basin (orogenward). The coarse-grained deposits ("basal clastics/Detrit" - possibly equivalent of Dębowiec conglomerate?) deposited at the base of the Central Depression should be therefore partly stratigraphically older than the "basal clastics" filling the palaeovalley (Žukov Fm.) and might represent "lowstand clastic wedge" in the sense of sequence stratigraphy. The limited thickness of "Detrit" in the adjacent part of the Central Depression to the Odra palaeovalley (boreholes BL-1, NP-637) could reflect a further redistribution of the material along the basin axes (i.e. generally towards the $E$ and/or SW). However, it is possible, that also the lowermost part of the Odra valley-fill (possible colluvial beds of FA 1) comprises (partly?) basal alluvium.

Stage B: this stage reflects the switch from incision and sediment bypassing to sediment accumulation. The basal unconformity of the Odra palaeovally is uneven in the longitudinal profile (Fig. 1C) and covered by the succession FA 1-FA 2-FA 3-FA 2 (see Fig. 6A), which represents a sedimentary response to the condition during stage B. FA 1, FA 2 and FA 3 deposits reflect a high-gradient alluvial feeder dominated by sediment gravity flows and/or high magnitude waterflows and preserve sensitive records of variable tectonic, climate and base-level conditions.

The thick vertically stacked conglomeratic wedges of stage 2 reveal, in detail, repetitive variations in the A/S ratio across time and space (e.g., successive fan prograding-retreating episodes alternating with aggrading stage). Aggradation and progradation are generally consistent with sediment overloading/low rates of $\mathrm{A} / \mathrm{S}$ ratio and deposition of thick bedded crudely stratified conglomerates. Retrogradation is consistent with sediment undersupply, i.e. higher rates of the A/S ratio and deposition of more thinly bedded gravels with higher facies variations. The strong prevalence of debris flow deposits and the relatively stable source rock lithology through alluvial deposition of stage B point to generally similar upstream conditions and a limited role of climate (variations in frequency and magnitude of rainfall events, humid versus arid conditions) on deposition (e.g., Blair, 1999; Andreucci et al., 2014). Evidence of FA 3 within FA 2 de- 


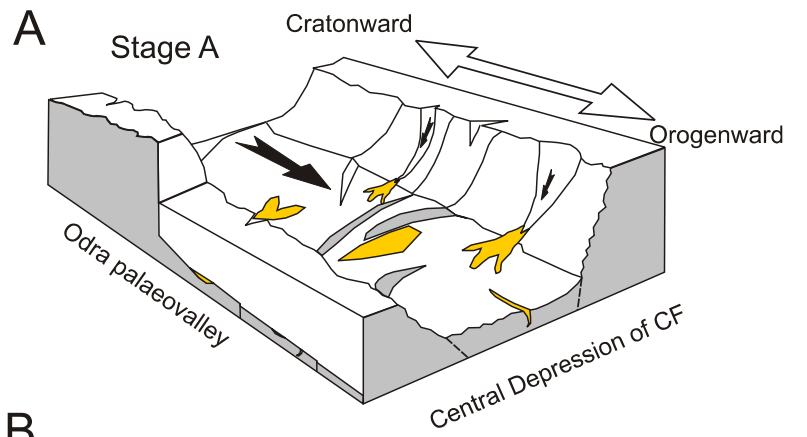

B

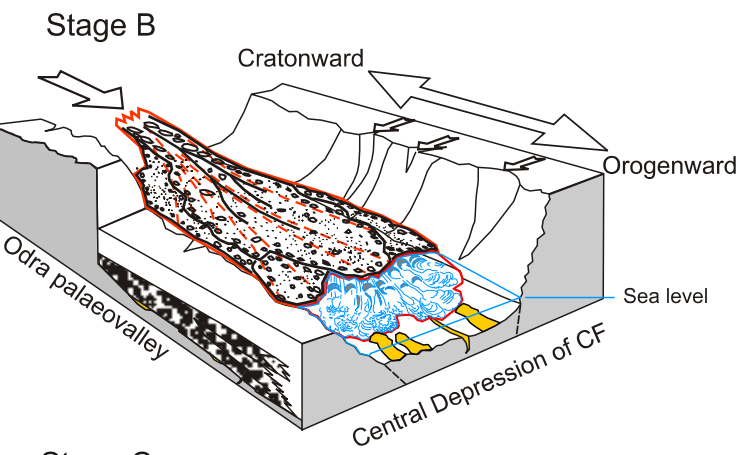

\section{C}

Stage C

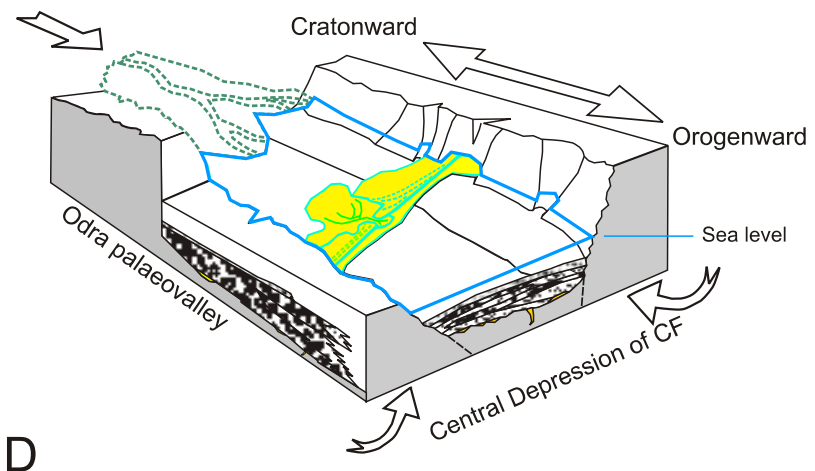

Stage D

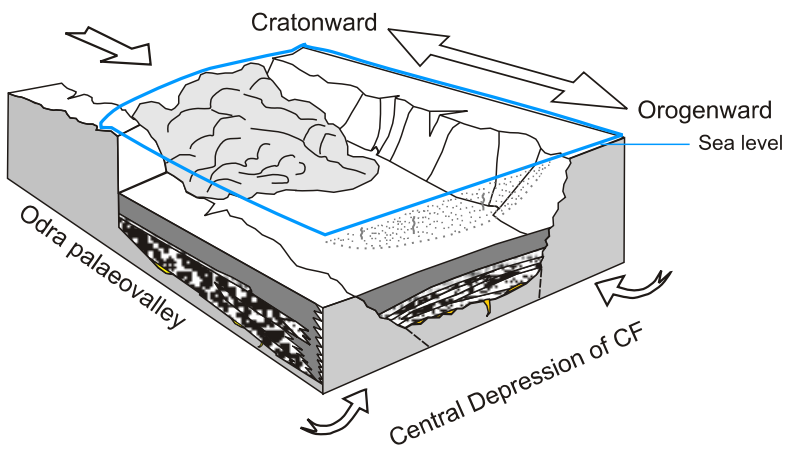

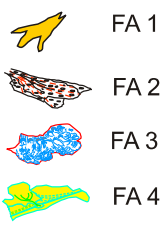

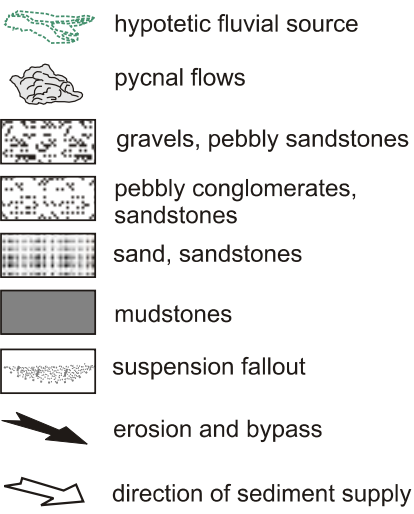

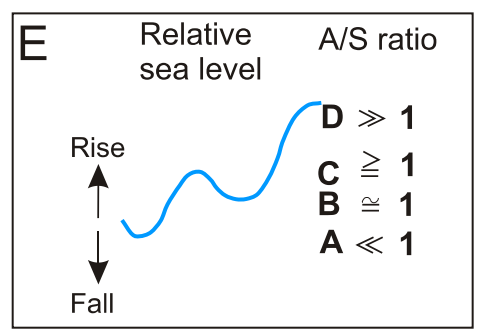

Fig. 12. Schematic model of the evolution of the deposition of the Odra palaeovalley

A - reconstruction of the situation during stage A (Paleogene-Early Miocene). Increased crustal loading by a thickened orogenic wedge (Western Carpathian Flysch nappes) results in subsidence of the inner part of the foredeep, uplift of the forebulge and initial valley entrenchment. Possible initiation of deposition of FA 1; B - situation during stage $\mathrm{B}$ (Early/Middle Miocene). The initial marine transgression drowned the central depression and the entry of the palaeovalley. The derivation of the material mostly from passive/cratonward margin of the basin. Little role of provenance from active margin/orogenward. Deposition of FA 1+ FA 2 and FA 3; C - situation during stage $C$ (Early/Middle Miocene-Early Badenian). Continued transgression and cratonward shift of the flexure led to the formation of basin embayment and nearshore deposition. Deposition of FA 4; D - situation during stage $\mathrm{D}$ (Early Badenian). Continued transgression and cratonward shift of the flexure, deep drowning of the former palaeovalley and adjacent area (far cratonward). Deposition of FA 5; E - simplified relative sea level history and $A / S$ ratio interpreted from the sedimentary infill of the Odra palaeovalley $(A, B, C, D$ - stages of the palaeovalley evolution); 1 - FA 1;2 - FA 2; 3 - FA 3; 4 - FA 4; 5, 6-Pycnal Flows; 7 - gravels, pebbly sandstones; 8 - pebbly conglomerates, sandstones; 9 - sand, sandstones; 10 - mudstones; 11 - suspension fallout; 12 - erosion and bypass; 13 - direction of sediment supply 
posits points to sea flooding of the lower segment/entry of the entrenched valley, the role of ponding water at the valley downstream boundary and the state when the rate of accommodation development outpaced rate of sediment supply (Fig. 12B). Although, the graben-like MCF basin central depression restricted transgression (e.g., Postma, 1995; Kempf and Pfiffner, 2004), the alluvial gradient within the Odra palaeovalley was flattened by the base level rise. The high sediment discharge and topographically restricted confinement minimize sediment dispersal and downfan energy dissipation, boosts sediment aggradation and progradation through the valley, determine the geometry of the fan, minimize channel branches, fan segmentation and facies distribution (e.g., Nemec and Steel, 1988).

$\mathrm{A} / \mathrm{S}$ changes on the forebulge are flexurally induced and connected both with an uplift of the forebulge/hinterland (responsible for "continuous" high sediment supply) and with relative sea level rise (responsible for a "continuous" rise of the accommodation space) enabling alluvial system to keep pace with the rising relative sea level. The dominance of conglomerates throughout the succession implies that the coarse-grained debris was delivered by high-energy flows from a relatively proximal and stable source, alluvial fan with a very steep gradient, overfilling and deposition in a relatively narrow/confined area (sensu Postma, 1990). The high sediment supply was induced by the erosion of the uplifted hinterland. The combination of a small drainage basin and high-intensity precipitation events might be responsible for generating abundant high-energy floods delivering the coarse-grained material (Gupta, 1999).

The alluvial facies apparently developed near the basin margin and its sediment supply was high and rapid enough to keep a steep front and slope of the fan/fan-delta, preventing complete reworking by waves or further marine processes. This implies that the relative sea level rise has been superimposed on tectonic activity, and also these tectonics related to contemporary thrusting processes in the Western Carpathians were the principal ruling factor of deposition during stage $B$. The thickness of the valley-fill succession strongly increases in the central part of the valley pointing to synsedimentary activity of the valley border faults. Calvache et al. (1997) and Viseras et al. (2003) recognized that the high role of tectonic subsidence and topographic differences between the fan and the source area favours alluvial aggradation and development of small fans with a constant steep slope lacking incised channels, trenches and gullies. These fans are comparatively smaller in relation to their drainage areas than fans directed by base level rise. In systems controlled primarily by tectonics the longitudinal fan profiles have a constant or even concave slope which favours aggradation.

The deposits of stage B are a product of the erosion of structurally controlled topography and are partly unrelated of sea level variations. No marine strata with marine fossils was recognized as interbeds within the deposits of stage B. However, provenance studies proved partial source from the active (orogenward) basin margin and therefore such marine interbeds might locally existed and were destroyed by the alluvial erosion.

The configuration of the alluvial feeder system has a crucial influence on the gross geometry of alluvial fan/fan-delta. The existence of a simple feeder trunk is here questioned due to the presence of outsized mostly angular boulders or blocks which lack evidence of transport and abrasion prior to deposition. A combination of both longitudinal and transverse input is therefore supposed. These sources differ in length of transport and gradient and their actual role varied through succession. Direct input of local material (transverse input) was more evident in the beginning of stage B. The longitudinal (i.e. from the NW) supply was relatively more pronounced in the upper part of succession, where pebbles are more rounded and size sorting is evident.

Stage C: the gradual sea level rise, high sediment supply and aggradation of coarse-grained deposits (see the upper FA 2 package) within the confined palaeovalley led to flattening of the feeder profile and reduction of the sediment delivery into the valley/basin. Reduced delivery might be also connected with early phases of the forebulge retreat (Plint et al., 1993; Leszczyński and Nemec, 2015). The subsequent increase of the A/S ratio is reflected by deposition of FA 4 (nearshore deposits). Reduction of the grain-size of FA 4 points to its up-valley entrapment, retrogradation of the feeder progressively upstream contemporaneously with marine flooding of the valley, some enlargement of the available space to fill, a cratonward shift of the facies belts and reworking of the input by waves or tides. As the embayment was increasingly drowned and its sheltering effect decreased (sensu Yoshida et al., 2007). A continued transition of the shoreline conditions to a shallow marine ones is supposed from the NW to SE along the palaeovalley axis (Fig. 12C) and upward the sedimentary pile of FA 4. The embayed geometry of the valley might have been prone to an extended sand flat formation. The alluvial fan, which might still reflect a tectonic margin of the basin, moved towards the source area.

The deposits of stage $\mathrm{C}$ might be compared with the start of Early to Middle Miocene 3rd order cycle TB 2.3. (Kováč et al., 2004; Hohenegger et al., 2014) however, the micropalaeontological evidence in unclear. The inundation of the valley is assumed to have been relatively rapid (small lateral extent of the valley, flat upper surface of FA 2). The deposits of stage B deposits were covered and cratonwards overstepped by the transgressive succession of stage C (i.e. FA 4 deposits).

Stage D: this stage reflects a rapid forebulge flexural retreat, further back-stepping of valley infill, marine invasion with a shift of the coastline further landward (coastal onlap onto the foreland plate), significant enlargement of the basin (far beyond the palaeovalley), a change in the basin bathymetry and increased sediment supply from the active margin. A dramatical increase of $A$ and further reduction of $S$ led to a deposition of a thick mudstone pile of FA 5. Stage D represents a continuation (see stage $\mathrm{C}$ ) of flexurally induced marine transgression (base-level rise). The general north-westward-stepping coastal onlap has been modified by the pre-existing local relief (Fig. 12D).

The Early Badenian evolution of the MCF is in general characterized by NW-directed, stepwise transgressions onto the NW basin margin followed by stationary or even regressive phases (Nehyba et al., 2016; Holcová et al., 2018). The presented data support an overall trend of the transgression of neritic facies onto the distal foreland margin, which occurred with rapid steps (probably tens of kilometres). Micropalaeontology proved that the deposits of FA 5 are connected with the 3rd order cycle TB 2.4. (Haq et al., 1988; Kováč et al., 2004; Hohenegger et al., 2014).

The studied Miocene succession depict an upward-deepening facies succession. The passages between proposed stages A to $D$ seem to be generally abrupt, suggesting a disjunction between them. Several episodes of flooding, recognized within the succession point to a complicated depositional history of the MCF during the Lower/Middle Miocene transition where eustatic sea level fluctuations superimposed on the dominant flexural background subsidence are locally accelerated by normal faulting (Haq et al., 1988; Miller et al., 1998; Allen et al., 2001). The formation and filling of the Odra palaeovalley (today preserved as a narrow graben) was accompanied by the creation of accommodation further to the NW than contemporaneous deposits occur today. 


\section{CONCLUSIONS}

The Miocene fining-up and deepening-up sedimentary succession (almost $300 \mathrm{~m}$ thick) was studied within the confined Odra palaeovalley entrenched into the bedrock of the distal margin of the Moravian Carpathian Foredeep (peripheral foreland basin). Five facies associations/depositional environments have been recognized within the sedimentary succession evolved during several successive stages.

The initiation of the pallaeovalley evolution/stage $A$ is connected with increased crustal loading of the Western Carpathian thrust pile, arching of the forebulge and reactivation of the basement faults (Early Miocene?). Here, the bedrock-confined Odra palaeovalley developed within the forebulge zone along the NW-SE trending basement faults perpendicular to the basin main axis. A steep base level profile and base level fall (Early/Middle Miocene in age?) led to negative accommodation and entrenchement of the depression. The sequence boundary/basal unconformity of the valley succession was formed. Moreover, formation of the marginal fault of the Carpathian Foredeep Basin (NE-SW trending) led to partial separation of the basement into several blocks.

Stage B represents the switch from incision and sediment bypassing to sediment accumulation and overfilling. Deposits of facies associations 1 (colluvial deposits to alluvial fan), 2 (alluvial fan) and 3 (fan-delta) represent the sedimentary infill of this stage and volumetrically predominant $(>77 \%)$ part of the studied Miocene succession. These deposits reflect the existence of a high-gradient alluvial feeder dominated by sediment gravity flows and/or high magnitude waterflows within a morphologically confined valley. The thick vertically stacked conglomeratic wedges of stage $B$ reveal in detail several phases of aggradation, progradation and retrogradation i.e. repetitive variations in accommodation/supply ratio across time and space. Changes in both accommodation and supply are interpreted as flexurally induced and connected both with fault activity (responsible for a "continuous" high sediment supply) and with relative sea level rise (responsible for a "continuous" rise of accommodation space) enabling the alluvial system to keep pace with the rising relative sea level. The fan-delta deposits re- veal flooding of the lower segment/entry of the valley by the sea.

Stage $\mathrm{C}$ reveals a further gradual sea level rise, flattening of the feeder profile, reduction of the sediment delivery, increase of the accommodation/supply ratio, transformation of the valley into a coastal embayment and is represented by deposition of facies association 4 (nearshore deposits). Reduction of the grain-size of FA 4 deposits points to its up-valley entrapment. Retrogradation of the alluvial feeder progressively upstream contemporaneously with marine flooding of the valley and cratonward shift of the facies belts might already reveal early phases if the forebulge retreat.

The final stage $D$ reflects a rapid forebulge flexural retreat, marine invasion on the foreland plate, northwestward recession of the basin margin, significant enlargement of the basin (far beyond the pallaeovalley) and change in its bathymetry. The dramatic increase of accommodation and further reduction of supply led to the deposition of thick open marine mudstone pile of facies association 5. The Early Badenian age of deposits of stages $C$ and $D$ is micropalaeontologically proved. An overall trend of transgression of neritic facies onto the distal foreland margin occurred by several steps.

Continued deepening of the basin can be followed through the studied Miocene sedimentary succession. The recognized stages and facies associations are connected with the forebulge response to tectonic pulses, related to contemporary thrusting processes in the Western Carpathians, combined with the effects of sediment supply and eustatic sea level changes. Tectonics is assumed to have been the principal ruling factor at the expense of eustatic sea level changes. Provenance studies indicate that the Lower Carboniferous clastic "Culmian facies" of the Moravian-Silesian Paleozoic and the older Carpathian Foredeep Basin infill (Karpatian in age?) represent the principal sources for the studied Miocene succession.

Acknowledgement: The study was supported by internal grant of Czech Geological Survey No. 322300 (Publications on drilling, geophysical and geochemical data from the project "Review of groundwater resources in the Czech Republic"). The manuscript benefited from the reviews of S. Leszczyński, P. Krzywiec and an unknown reviewer.

\section{REFERENCES}

Adámek, J., Brzobohatý, R., Pálenský, P., Šikula, J., 2003. The Karpatian in the Carpathian Foredeep (Moravia). In: The Karpatian, a Lower Miocene Stage of the Central Paratethys (eds. R. Brzobohatý, I. Cicha, M. Kováč and F. Rögl): 75-92. Masaryk University, Brno.

Adams, J.A.S., Weaver, E., 1958. Thorium to uranium ratios as indicators of sedimentary process: example of concept of geochemical facies. AAPG Bulletin, 42: 387-430.

Akinlotan, O., 2017. Geochemical analysis for palaeoenvironmental interpretations - a case study of the English Wealden (Lower Cretaceous, south-east England). Geological Quarterly, 61 (1): 227-238.

Allen, P.A., Burgess, P.M., Galewsky, J., Sinclair, H.D., 2001. Flexural-eustatic numerical model for drowning of the Eocene perialpine carbonate ramp and implications for Alpine geodynamics. Geological Society of America Bulletin, 113: 1052-1066.

Andreucci, S., Panzeri, L., Martini, P., Maspero, F., Martini, M., Pascucci, V., 2014. Evolution and architecture of a West Medi- terranean Upper Pleistocene to Holocene coastal Apron-fan system. Sedimentology, 61: 333-361.

Baker, G.S., 1999. Processing Near-Surface Seismic-Reflection Data: a Primer. Society of Exploration Geophysicists.

Backert, N., Ford, M., Malartre, F., 2010. Architecture and sedimentology of the Kerinitis Gilbert-type fan delta, Corinth Rift, Greece. Sedimentology, 57: 543-586.

Beaumont, C., 1981. Foreland basins. Geophysical Journal of the Royal Astronomical Society, 65: 291-329.

Benvenuti, M., 2003. Facies analysis ant tectonic signifikance of lacustrine fan-deltaic successions in the Pliocene-Pleistocene Mugello Basin, Central Italy. Sedimentary Geology, 157: 197-234.

Berggren, W.A., Kent, D.V., Swisher, C.C. III., Aubry, M.P., 1995. A revised Cenozoic geochronology and chronostratigraphy. Society of Sedimentary Geology, Special Publication, 54: 129-212.

Blair, T.C., 1999. Cause of dominance by sheet-flood vs. debris-flow processes on two adjoining alluvial fans, Death Valley, California. Sedimentology, 46: 1015-1028. 
Blair, T.C., McPherson, P., 1995. Quaternary alluvial fans of southwestern Crete: sedimentation processes and geomorphic evolution. Sedimentology, 42: 531-549.

Blum, M.D., Törnqvist, T.E., 2000. Fluvial responses to climate and sea-level change. A review and look forward. Sedimentology. 47: 2-48.

Breda, A., Mellere, D., Massari, F., 2007. Facies and processes in a Gilbert-delta-filled incised valley (Pliocene of Ventimiglia, NW Italy). Sedimentary Geology, 200: 31-55.

Breda, A., Mellere, D., Massari, F., Asioli, A., 2009. Vertically stacked Gilbert-type deltas of Ventimiglia (NW Italy): the Pliocene record of an overfilled Messinian incised valley. Sedimentary Geology, 219: 58-76.

Bruhn, R., Steel, R., 2003. High-resolution sequence stratigraphy of a clastic foredeep succession (Paleocene, Spitsbergen): an example of peripheral-bulge controlled depositional architecture. Journal of Sedimentary Research, 73: 745-755.

Brzobohatý, R., Cicha, I., 1993. Karpatská předhlubeň (in Czech). In: Geologie Moravy a Slezska (eds. A. Přichystal, V. Obstová and M. Suk): 123-128. MZM a PřF MU Brno.

Bubík, M., Břízová, E., Buriánek, D., Gilíková, H., Havír, J., Janderková, J., Kašperáková, D., Knésl, I., Kolejka, V., Konečný, F., Krejčí, O., Kryštofová, E., Otava, J., Pecina, V., Pořádek, P., Sedláček, J., Sedláčková, I., Švábenická, L., Skácelová, Z., Tomanová Petrová, P., Večeřa, J., Vít, J., 2018. Vysvětlivky k základní geologické mapě České republiky 1:25 000 list 25-132 Lipník nad Bečvou (in Czech). Czech Geological Survey, Prague (complex of the map and the explanatory text).

Calvache, M.L., Viseras, C., Fernández, J., 1997. Controls on fan development - evidence from fan morphology and sedimentology, Sierra Nevada, SE Spain. Geomorphology, 21: 69-84.

Catuneanu, O., Sweet, A.R., 1999. Maastrichtian-Paleocene foreland-basin stratigraphies, western Canada: a reciprocal sequence architecture. Canadian Journal of Earth Sciences, 36: 685-703.

Catuneanu, O., Willis, A.J., Miall, A.D., 1998. Temporal significance of sequence boundaries. Sedimentary Geology, 121 157-178.

Chlupáč, I., Brzobohatý, R., Kovanda, J., Stráník, Z., 2002 Geologická minulost České republiky (in Czech). Academia, Praha.

Cogan, J., Lerche, I., Dorman, J.T., Kanes, W., 1993. Flexural plate inversion: application to the Carpathian Foredeep, Czechoslovakia. Modern Geology, 17: 355-392.

Colella, A., De Boer, P.L., Nio, S.D., 1987. Sedimentology of a marine intermontane Pleistocene Gilbert-type fan-delta complex in the Crati Basin, Calabria, southern Italy. Sedimentology, 34: 721-736.

Czudek, T., 1971. Geomorfologie východní části Nízkého Jeseníku (in Czech). Rozpravy ČSAV, ř. mat. a prír. Věd. 81 (7): 1-90. Academia, Praha.

Čopjaková, R., Sulovský, P., Otava, J., 2002. Comparison of the chemistry of detritic pyrope-almandine garnets of the Luleč Conglomerates with the chemistry of granulite garnets from the Czech Massif (in Czech). Geological Research in Moravia and Silesia, 9: 44-47.

Dalrymple, R.W., 2004. Incised valleys in time and space: an inroduction to the volume and examination of the controls on valley formation and filling. Society of Sedimentary Geology, Special Publication, 85: 5-12.

Dietrich, P., Ghienne, J.F., Schuster, M., Lajeunesse, P., Nutz, A., Deschamps, R., Roquin, C., Duringer, P., 2017. From outwash to coastal systems in the Portneuf-Forestvilledeltaic complex (Quebec North Shore): anatomy of a forcedregressive deglacial sequence. Sedimentology, 64: 1044-1078.

Doláková, N., Brzobohatý, R., Hladilová, Š., Nehyba, S., 2008. The red-algal facies of the Lower Badenian limestones of the Carpathian Foredeep in Moravia (Czech Republic). Geologica Carpathica, 62: 133-146.

Doveton, J.H., Merriam, D.F., 2004. Borehole petrophysical chemostratigraphy of Pennsylvanian black shales in the Kansas subsurface. Chemical Geology, 206: 249-258.
Eliáš, M., Pálenský, P., 1998. Model vývoje miocénních předhlubní v okolí Ostravy (in Czech). Geoscience Research Reports in the year 1997: 65-66

Eliáš, M., Pálenský, P., Růžička, M., 2002. Litostratigrafie miocénu na severí Moravě a její litologické korelace $s$ přilehlým miocénem $\vee$ Polsku (karpatská předhlubeň) (in Czech). Geoscience Research Reports in the year 2001: 22-24.

Fernández, L.P., Agueda, J.A., Colmenero, J.R., Salvador, C.I., Barba, P., 1988. A coal-bearing fan-delta complex in the Westphalian D of the Central Coal Basin, Cantabrian Mountains, northwestern Spain: imlications for the recognition of humid-type fan deltas. In: Fann Deltas: Sedimentology and Tectonic Settings (eds. W. Nemec and R.J. Steel): 286-302. Blackie and Son.

Filková, V., 1984. Blahutovice JE. Seizmokarotážní měření na hlubinném vrtu Blahutovice-1 (in Czech). Technical Reports.

Francírek, M., Nehyba, S., 2016. Evolution of the passive margin of the peripheral foreland basin: an example from the Lower Miocene Carpathian Foredeep (Czech Republic). Geologica Carpathica, 67: 39-66.

Francírek, M., Otava, J., Nehyba, S., 2014. Provenience sedimentnů karpatu (Miocen) v centrální části karpatské předhlubně (okolí Kroměříže a Zlína) na základě přdběžného zhodnocení společenstva detritických granátů (in Czech). Geoscience Research Reports in the year 2013, 47: 101-103.

Franců, J., Otava, J., 2014. Depositional, thermal, and erosional history along and across to the Variscan Front, Czech Republic. Central European Meeting of Sedimentary Geology, Abstracts, Olomouc: $22-23$.

Folk, R.L., Ward, W., 1957. Brazos River bar: a study in the significance of grain-size parameters. Journal of Sedimentary Petrology, 27: 3-26.

Gawthorpe, R.L., Colella, A., 1990. Tectonic controls on coarse-grained delta depositional systems in rift basins. International Association of Sedimentologists Special Publication, 10: 113-127.

Gilíková, H., Nývlt, D., Pálenský, P., Petrová, P., Maštera, L., 2006. New findings based on geological mapping on the sheet 25-122 Suchdol nad Odrou (in Czech). Geological Research in Moravia and Silesia in the year 2005: 68-71.

Głuszyński, A., Aleksandrowski, P., 2016. A deep palaeovalley in the floor of the Polish Carpathian Foredeep Basin near Pilzno and its control on Badenian (Middle Miocene) evaporite facies. Geological Quarterly, 60 (2): 493-516.

Gobo, K., Ghinassi, M., Nemec, W., 2014. Reciprocal changes in foreset to bottomset facies in a Gilbert-type delta: response to short-term base level changes: delta brink morphodynamics and related foreset facies. Journal of Sedimentary Research, 84: 1079-1095.

Gupta, S., 1999. Controls on sedimentation in distal margin pallaeovalleys in the Early Tertiary Alpine foreland basin, south-eastern France. Sedimentology, 46: 357-384.

Hampson, G.J., Davies, W., Davies, S.J., Howell, J., Adamson, K.R., 2005. Use of spectral gamma-ray data to refine subsurface fluvial stratigraphy: late Cretaceous strata in the Book Cliffs, Utah, USA. Journal of Geological Society, 162 603-621.

Haq, B.U., Hardenbol, J., Vail, P.R., 1988. Mesozoic and Cenozoic chronostratigraphy and cycles of sea-level change. Society of Sedimentary Geology, Special Publication, 42: 71-108.

Hasselbo, S.P., 1996. Stratigraphy, Cenozoic of the Atlantic margin, offshore New Jersey. In: Proceedings of the Ocean Drilling Program (eds. G.S. Mountain, K.G. Miller, P. Blum, C.W. Poag and D.C Twichell): 411-422. Scientific Results, 150

Hartley, A.J., Otava, J., 2001. Sediment provenance and dispersal in a deep marine foreland basin: the Lower Carboniferous Culm Basin, Czech Republic. Journal of the Geological Society, 158: 137-150.

Hladilová, Š., Nehyba, S., Zágoršek, K., Tomanová Petrová, P., Bitner, M.A., Demeny, A., 2014. Early Badenian transgression on the Outer flank of Western Carpathian Foredeep, Hluchov area, Czech Republic. Annales Societatis Geologorum Poloniae, 84: 259-278. 
Hohenegger, J., Ćorić, S., Wagreich, M., 2014. Timing of the Middle Miocene Badenian Stage of the Central Paratethys. Geologica Carpathica, 65: 55-66.

Holcová, K., Doláková, N., Nehyba, S., Vacek, F., 2018. Timing of Langhian bioevents in the Carpathian Foredeep and north ern Pannonian Basin in relation to oceanographic, tectonic and climatic processes. Geological Quarterly, 62 (1): 3-17.

Hubert, J.F., 1962. A zircon-tourmaline-rutile maturity index and the interdependence of the composition of heavy mineral assemblages with the gross composition and texture of sandstones. Journal of Sedimentary Research, 32: 440-450.

Hubert, J.F., Hyde, M.G., 1982. Sheet-flow deposits of graded beds and mudstones on an alluvial sandflat-playa system: Upper Triassic Blomindon Redbeds, St Mary's Bay, Nova Scotia. Sedimentology, 29: 457-475.

Hwang, I.G., Chough, S.K., 2000. The Maesan fan delta, Miocene Pohang Basin, SE Korea: architecture and depositional processes of a high-gradient fan-delta-fed slope system. Sedimentology, 47: 995-1010.

Jarosiński, M., Poprawa, P., Ziegler, P.A., 2009. Cenozoic dynamic evolution of the Polish Platform. Geological Quarterly, $\mathbf{5 3}$ (1): 3-26.

Jervey, M.T., 1988. Quantitative geological modeling of siliciclastic rock sequences and their seismic expression. Society of Economic Paleontologists and Mineralogists Special Publication, 42: 47-69.

Jurková, A., 1959. Závislost miocénních basálních klastik na reliéfu karbonu a na neogenní tektonice $v$ nových důlních polích na Stonavě (in Czech). Věstník ÚúG, 34: 31-44.

Jurková, A., 1961. Reliéf karbonu a výskyty miocénních bazálních klastik v ostravsko-karvinském revíru (in Czech). Přírodovědný časopis slezský, 22: 311-326.

Jurková, A., 1971. Vývoj badenske čelní hlubiny v Moravské bráně a na Ostravsku (in Czech). Geologické Práce, Správy, 57: 155-160.

Jurková, A., 1985. Moravská brána jako dědičná depresní morfostruktura (in Czech). Sborník GPO, 29: 129-133.

Jurková, A., Molčíková, V., Čtyroký, P., Polický, J., 1983. New Eggenburgian finds in NE Moravia (in Czech with English summary). Geologické Práce, Správy, 79: 153-168.

Kalvoda, J., Bábek, O., Fatka, O., Leichmann, J., Melichar, R. Nehyba, S., Špaček, P., 2008. Brunovistulian terrane (Bohemian Massif, Central Europe) from late Proterozoic to late $\mathrm{Pa}$ leozoic: a review. International Journal of Earth Sciences, 97: 497-517.

Karnkowski, P., 1989. Deltaic deposits of the Carpathian foreland (in Polish with English summary). Przegląd Geologiczny, 37: 28-32.

Kempf, O., Pfiffner, O.A., 2004. Early Tertiary evolution of the North Alpine Foreland Basin of the Swiss Alps and adjoining areas. Basin Research, 16: 549-567.

Kopecká, J., 2012. Foraminifera as environmental proxies of the Middle Miocene (Early Badenian) sediments of the Central Depression (Central Paratethys, Moravian part of the Carpathian Foredeep). Bulletin of Geosciences, 87: 431-442.

Kováč, M., Grigorovich, A.A., Brzobohatý, R., Fodor, L., Harzhauser, M., Oszczypko, N., Pavelić, D., Rögl, F., Saftić, B., Sliva, L'., Stráník, Z., 2003. Karpatian paleogeography, tectonics and eustatic changes. In: The Karpatian, a Lower Miocene Stage of the Central Paratethys (eds. R. Brzobohatý I. Cicha, M. Kováč and F. Rögl): 49-73. Masaryk University, Brno.

Kováč, M., Baráth, I., Harzhauser, M., Hlavatý, I., Hudáčková, N., 2004. Miocene depositional systems and sequence stratigraphy of the Vienna basin. Courier Forschungsinstitut Senckenberg, 246: 187-212.

Krysiak, Z., 2000. Tectonic evolution of the Carpathian Foredeep and its influence on Miocene sedimentation. Geological Quarterly, 44 (2): 137-156.

Krzywiec, P., 1997. Large-scale tectono-sedimentary Middle Miocene history of the central and eastern Polish Carpathian Foredeep Basin - results of seismic data interpretation. Przegląd Geologiczny, 45: 1039-1053.
Krzywiec, P., 2001. Contrasting tectonic and sedimentary history of the central and eastern parts of the Polish Carpathian foredeep basin - results of seismic data interpretation. - Marine and Petroleum Geology, 18: 13-38.

Leszczyński, S., Nemec, W., 2015. Dynamic stratigraphy of composite peripheral unconformity in a foredeep basin. Sedimentology, 62: 645-680.

López-Blanco, M., Marzo, M., Piña, J., 2000. Transgressive-regressive sequence hierarchy of foreland, fan-delta clastic wedges (Montserrat and Sant Llorenç del Munt, Middle Eocene, Ebro Basin, NE Spain). Sedimentary Geology, 138: 41-69.

Lowe, D.R., 1982. Sediment gravity flows: II. Depositional models with special reference to the deposits of high-density turbidity currents. Journal of Sedimentary Petrology, 52: 279-297.

Maejima, W., 1988. Marine transgression over an active alluvial fan: the early Cretaceous Arida Formation, Yuasa-Aridagawa Basin, southwestern Japan. In: Fan Deltas: Sedimentology and Tectonic Settings (eds. W. Nemec and R.J. Steel): 303-317. Blackie and Son.

Mange-Rajetzky, M.A., 1995. Subdivision and correlation of monotonous sandstone sequences using high-resolution heavy-mineral analysis, a case study: the Triassic of the Central Graben. Geological Society, London, Special Publications, 89: 23-31.

Marzo, M., Anadón, P., 1988. Anatomy of conglomeratic fan-delta complex: the Eocene Montserrat Conglomerate, Ebro Basin, northeastern Spain. In: Fan Deltas: Sedimentology and Tectonic Settings (eds. W. Nemec and R.J. Steel): 318-340. Blackie and Son.

Miller, K.G., Mountain, G.S., Browning, J.V., Kominz, M., Sugarman, P.J., Christie-Blick, N., Katz, M.E., Wright, J.D., 1998. Cenozoic global sea level, sequences, and the New Jersey Transect: results from coastal plain and continental slope drilling. Reviews of Geophysics, 36: 569-601.

Morton, A.C., Berge, C., 1995. Heavy mineral suites in the Statfjord and Nansen Formations of the Brent Field, North Sea: a new tool for reservoir subdivision and correlation. Petroleum Geoscience, 1: 355-364.

Morton, A.C., Hurst, A., 1995. Correlation of sandstones using heavy minerals: an example from the Statfjord Formation of the Snorre Field, northern North Sea. Geological Society, London, Special Publications, 89: 3-23.

Muto, T., Steel, R.J., 1997. Principles of regression and transgression: the nature of the interplay between accommodation and sediment supply. Journal of Sedimentary Research, 67: 994-1000.

Myers, K.J, Bristow, C.S., 1989. Detailed sedimentology and gamma-ray log characteristics of a Namurian deltaic succession, II. Gamma-ray logging. Deltas: sites and traps for fossil fuels. Geological Society, London, Special Publications, 41: 81-88.

Myers, K.J., Wignall, P.B., 1987. Understanding Jurassic organic-rich mudrocks - new concepts using gamma-ray spectrometry and palaeoecology: examples from the Kimmeridge Clay of Dorset and the Jet Rock of Yorkshire. In: Marine Clastic Sedimentology (eds. J.K. Legget and G.G. Zuffa): 172-189. London, Graham and Trotman.

Nehyba, S., Roetzel, R., 2010. Fluvial deposits of the St. Marein-Freischling Formation - insights into initial depositional processes on the distal external margin of the Alpine-Carpathian Foredeep in Lower Austria. Austrian Austrian Journal of Earth Sciences, 103: 50-80.

Nehyba, S., Šikula, J., 2007. Depositional architecture, sequence stratigraphy and geodynamic development of the Carpathian Foredeep (Czech Republic). Geologica Carpathica, 58: 53-69.

Nehyba, S., Roetzel, R., Adamová, M., 1999. Tephrostratigraphy of the Neogene volcaniclastics (Moravia, Lower Austria, Poland). Geologica Carpathica, 50 (Spec. Iss.): 126-128.

Nehyba, S., Tomanová Petrová, P., Zágoršek, K., 2008. Sedimentological and palaeocological records of the evolution of the south-western part of the Carpathian Foredeep (Czech Republic) during the Early Badenian. Geological Quarterly, 52 (1): 45-60.

Nehyba, S., Gilíková, H., Tomanová Petrová, P., Čurda, J., 2009. Sedimentologické stadium spodnobadenských klastických 
sedimentů na vybraných odkryvech Moravské brány (in Czech). Geological Research in Moravia and Silesia, 16: 21-25.

Nehyba, S., Holcová, K., Gedl, P., Doláková, N., 2016. The Lower Badenian transgressive-regressive cycles - a case study from Oslavany (Carpathian Foredeep, Czech Republic). Neues Jahrbuch für Geologie und Paläontologie, 279: 209-238.

Nemec, W., 1990. Aspects of sediment movement on steep delta slopes. International Association of Sedimentologists Special Publication, 10: 29-74.

Nemec, W., 1995. The dynamics of deltaic suspension plumes. In: Geology of Deltas (eds. M.N. Oti and G. Postma): 31-93. Balkema, Rotterdam.

Nemec, W., Kazanci, N., 1999. Quaternary colluvium in the west-central Anatolia: sedimentary facies and palaeoclimatic significance. Sedimentology, 46: 139-170.

Nemec, W., Steel, R.J., 1984. Alluvial and coastal conglomerates: their significant features and some comments on gravelly mass-flow deposits. Canadian Society of Petroleum Geologists Memoir, 10: 1-31.

Nemec, W., Steel, R.J., 1988. What is a fan delta and how do we recognize it? In: Fan Deltas: Sedimentology and Tectonic Settings (eds. W. Nemec and R.J. Steel): 3-13. Blackie and Son.

Nichols, G., Thompson, B., 2005. Bedrock lithology control on contemporaneous alluvial fan facies, Oligo-Miocene, southern Pyrenees, Spain. Sedimentology, 52: 571-585.

Oszczypko, N., Ślączka, A., 1985. An atempt to palinspastic reconstruction of Neogene basins of the Carpathian Foredeep. Annales Societatis Geologorum Poloniae, 55: 55-75.

Oszczypko, N., Krzywiec, P., Popadyuk, I., Peryt, T., 2006. Carpathian Foredeep Basin (Polish and Ukraine): its sedimentary, structural, and geodynamic evolution. AAPG Memoir, 84: 293-350.

Otava, J., 1998. Trendy změny složení spodnokarbonských siliciklastických sedimentů Drahanské vysočiny (Morava) (in Czech). Geological Research in Moravia and Silesia in the year 1997: 62-64.

Otava, J. ed., Bábek, O., Bubík, M., Buriánek, D., Čurda, J., Franců, J., Fürychová, P., Geršl, M., Gilíková, H., Godány, J., Havír, J., Havlín Nováková, D., Krejčí, O., Krejčí, V., Lehotský, T., Maštera, L., Novotný, R., Poul, I., Sedláčková, I., Skácelová, D., Skácelová, Z., Stráník, Z., Švábenická, L., Tomanová Petrová, P., 2016. Vysvětlivky k základní geologické mapě České republiky 1:25 000 list 25-141 Kelč (in Czech). Geological map 1:25 000 with explanatory text. 116s. Czech Geological Survey, Prague (complex of the map and the explanatory text).

Picha, F., 1979. Ancient submarine canyons of Tethyan continental margins, Czechoslovakia. AAPG Bulletin, 63: 67-86.

Picha, F., Stránik, Z., Krejči, O., 2006. Geology and hydrocarbon resources of the Outer Western Carpathians and their foreland, Czech Republic. AAPG Memoir, 84: 49-175.

Plint, A.G., Hart, B., Donaldson, W.S., 1993. Lithospheric flexure as a control on stratal geometry and facies distribution in Upper Cretaceous rocks of the Alberta Foreland Basin. Basin Research, 5: 69-77.

Postma, G., 1984. Mass-flow conglomerates in a submarine canyon: Abrioja fan delta, Pliocene, Southeast Spain. Canadian Society of Petroleum Geologists, Memoir, 10: 237-258.

Postma, G., 1990. Depositional architecture and facies of river and fan deltas: a synthesis. International Association of Sedimentologists Special Publication, 10: 13-27.

Postma, G., 1995. Sea-level-related architectural trends in coarse-grained delta complexes. Sedimentary Geology, 98: 3-12.

Postma, G., Roep, T.B., 1985. Resedimented conglomerates in the bottomsets of Gilbert-type gravel deltas. Journal of Sedimentary Research, 55: 874-885.

Powers, M.C., 1982. Comparison chart for estimating roundness and sphericity. AGI Data Sheet 18.

Prior, P.D., Bornhold, B.D., 1990. The underwater development of Holocene deltas. International Association of Sedimentologists Special Publication, 10: 75-90.

Rees, A.I., 1968. Geological notes-the production of preferred orientation in a concentrated dispersion of elongated and flattened grains. The Journal of Geology, 76: 457-465.
Rider, M.H., 1996. The Geological Interpretation of Well Logs. John Wiley and Sons, Inc., New York.

Ruffell, A., Worden, R., 2000. Palaeoclimate analysis using spectral gamma-ray data from the Aptian (Cretaceous) of southern England and southern France. Palaeogeography, Palaeoclimatology, Palaeoecology, 155: 265-283.

Rust, B.R., 1978. Depositional models for braided alluvium. Canadian Society of Petroleum Geologists Memoir, 5: 605-625.

Sandmeier, J.K., 2000. Introduction to the Processing of Seismic Reflection Data within REFLEXW. RELEX W guide. Sandmeier Scientific Software, Germany.

Schnyder, J., Ruffell, A., Deconinck, J.-F., Baudin, F., 2006. Conjunctive use of spectral gamma-ray logs and clay mineralogy in defining late Jurassic-early Cretaceous palaeoclimate change (Dorset, U.K.). Palaeogeography, Palaeoclimatology, Palaeoecology, 229: 303-320.

Shanley, K.W., McCabe, P.J., 1994. Perspectives on the sequence stratigraphy of continental strata. American Association of $\mathrm{Pe}$ troleum Geologists Bulletin, 78: 544-568.

Sohn, Y.K., 2000. Depositional processes of submarine debris flows in the Miocene fan deltas, Pohang Basin, SE Korea with special reference to flow transformation. Journal of Sedimentary Research, 70: 491-503.

Somoza, L., Rey, J., 1991. Holocene fan deltas in a "Ria" morphology. Prograding clinoform types and sea-level control. Cuadernos de Geología Iberíca, 15: 37-48.

Talling, P.J., Masson, D.G., Sumner, E.J., Malgesini, G., 2012 Subaqueous sediment density flows: depositional processes and deposit types. Sedimentology, 59: 1937-2003.

Tomanová Petrová, P., 2016. Karpatian and Lower Badenian sediments on the locality Brus. Geoscience Research Reports, 49: 171-176.

Tomanová Petrová, P., Švábenická, L., 2007. Lower Badenian biostratigraphy and paleoecology: a case study from the Carpathian Foredeep (Czech Republic). Geologica Carpathica, 58: 333-352.

Tomek Č., Ibrmajer I., Cidlinský K., 1987. Variscan thrust tectonics in the Bohemian Massif - first results revealed by reflection seismology. In: The Rhenish Massif. Earth Evolution Sciences (eds. A. Vogel, H. Miller and R.Greiling). Vieweg + Teubner Verlag, Wiesbaden.

Tucker, M. ed., 1995. Techniques in Sedimentology. Blackwell Science, Oxford.

Viseras, C., Calvache, M.L., Soria, J.M., Fernandez, J., 2003. Differential features of alluvial fans controlled by tectonic or eustatic accommodation space. Examples from the Betic Cordillera, Spain. Geomorphology, 50: 181-202.

Walker, R.G., James, N.P., 1992. Facies Models: Response to Sea Level Changes. Geological Association of Canada, St. John's.

Waschbusch, P.J., Royden, L.H., 1992. Spatial and temporal evolution of foredeep basins: lateral strength variations and inelastic yielding in continental lithosphere. Basin Research, 4: 179-196.

Went, D.J., 2005. Pre-vegetation alluvial fan facies and processes: an example from the Cambro-Ordovician Rozel Conglomerate Formation, Jersey, Channel Islands. Sedimentology, 52: 693-713.

Wescott, W., Ethridge, F.G., 1982. Bathymetry and sediment dispersal dynamics along the Yallahs fan delta, Jamaica. Marine Geology, 46: 245-260.

Yoshida, S., Steel, R.J., Dalrymple, R.W., 2007. Changes in depositional processes - an ingredient in a new generation of sequence-stratigraphic models. Journal of Sedimentary Research, 77: 447-460.

Zaitlin, B.A., Dalrymple, R.W., Boyd, R., 1994. The stratigraphic organization of incised-valley systems associated with relative sea-level change. Society for Sedimentary Geology, Special Publication, 51: 45-60.

Zingg, T., 1935. Beitrag zur Schotteranalyse. Die Schotteranalyse und ihre Anwendung auf die Glattalschotter. Schweizerische Mineralogische und Petrographische Mitteilungen, 15: 39-140. 